\title{
Migrant Men in Misery \\ Result from a Qualitative Life History Analysis \\ on Individuals and Families Concerning Internal \\ Migration, Health and Life Circumstances in \\ Early 19th Century, Linköping, Sweden
}

\author{
Victoria Nygren
}

\section{Introduction}

The purpose of this paper is to present and evaluate the first results from an ongoing study, which aims to explore and understand, in a hermeneutic sense, under what life conditions, including their health, internal migrants lived, in a small pre-industrial Swedish town during a time of considerable social change, and also how these migrants coped with their everyday lives as new residents in town. ${ }^{1}$ In other words, under what circumstances could these migrants better their lives in town and under what circumstances was their strive for improvement hindered? After an introduction to previous research, followed by a presentation of the method used in this study and a characterization of the context of the town, Linköping, examples of migrant life courses will be presented and discussed.

Aside from the fact that the migrants experienced a change in their own lives when they changed their geographical and social setting, they are also considered as important objects to study, since migration to the towns from the countryside in itself was a vital part of this process of social change, profound and accelerated in scale during the 19th century. The traditional agrarian way of life was in retreat and the industrialized

1 This approach is inspired by a life course perspective that investigates the "interaction" between the individual, the family and the possibilities and limitations within the structure, see Tamara K. Hareven, "The History of the Family and the Complexity of Social Change", American Historical Review, vol. 96, no. 1 (1991), pp. 95-124. Quotation p. 111; Jan Sundin, "Worlds we have lost and worlds we may regain: Two centuries of changes in the life course in Sweden", The History of the Family, vol. 4, no. 1 (1999), pp. 93-112. 
way of life was yet to come. ${ }^{2}$ A capitalistic market had started to replace the more "feudal" economic system. ${ }^{3}$ At the same time, the rigid patriarchal order between different social groups in society was starting to loosen up. Still, there was some time before a more egalitarian and individualized social structure could emerge. ${ }^{4}$

Many people were proletarianised, mainly due to the increase in population and changes in the agrarian ways of production. A great deal of those were heading towards the towns looking for new ways to make their living and, hypothetically, for a more emancipated life. The regulations for permitting a migrant to stay in town were, however, strict during the first decades of the century and reflected the old social and economic system, both in the countryside and in the town, where everyone was expected to belong to a household under the surveillance of the head of the household, whether it was the owner of a farm or the master craftsman. The 'social welfare system' at work can retrospectively be judged as obsolete and not well-designed for the growing needs of these new groups of people 'in between' two systems of social structure. $^{5}$

The "social issue" of this period of time was debated among various representatives of Swedish society. ${ }^{6}$ It was, for instance, a popular conception among the ruling elite in towns that social misery, poverty, criminal and immoral behaviour and health problems had much to do with the invasion of migrants who came mostly from the countryside looking for a future. ${ }^{7}$ These ideas were by no means exclusive to Sweden and when spread to the middle classes they have later influenced social theory and modernization theory. ${ }^{8}$

The topic of how migrants who settled in new places during structural change managed, is indeed not a new one in research. It has been a field of discussion marked

2 Hilding Pleijel, Hustavlans värld: Kyrkligt folkliv i äldre tiders Sverige (Verbum, Stockholm, 1970), p. 69ff, 103ff. See Börje Harnesk's definition on "patriarchalism" in which "difference", "reciprocity" and "wholeness" are important criteria in a patriarchalistic relationship, in "Patriarkalism och lönearbete", Historisk tidskrift, vol. 3, (1986), pp. 330-331. Quotations are translated by the author of this paper.

3 Sture Martinius, Jordbrukets omvandling på 1700- och 1800-talen (Liber förlag, Lund, 1982), p. 5.

4 H. Pleijel (1970), p. 69ff, 103ff.

5 H. Pleijel (1970), p. 69, 104; Arthur Montgomery, Svensk socialpolitik under 1800-talet (Kooperativa förbundets bokförlag, Stockholm, 1951), p. 99f; Günter Sollinger, Sjuk- och begravningskassorna och andra understödskassor $i$ Kungl. bibliotekets samlingar (Kungliga biblioteket, Stockholm, 1985), pp. 20-28.

6 Birgit Petersson, "Debatten om 'Den sociala frågan", in Kontroll och kontrollerade: Formell och informell kontroll $i$ ett historiskt perspektiv, ed. Jan Sundin, Forskningsrapporter från Historiska institutionen vid Umeå universitet, no. 1 (Historiska institutionen vid Umeå universitet, Umeå, 1982), p. 88.

7 A. Montgomery (1951), p. $128 f$.

8 Charles Tilly, Big Structures, Large Processes, Huge Comparisons (Russell Sage Foundation, New York, 1984), pp. 1-13. 
by a "paradigmatic" shift in perspective since The Uprooted was first published in 1951. When Oscar Handlin focused on the dark side of the experiences of migration from Europe to North America in the 19th century, his critics modified this picture, a criticism against modernization theory that has been fundamental. ${ }^{10}$ "[I]deological" and "methodological" matters are said to be involved in those cases where the more nuanced analysis has been rejected for the sake of a hypothesis to be proved. ${ }^{11}$

At the same time, demographic research has been able to show that male mortality in pre-industrialized 19th century Sweden was higher due to causes that can be linked to "social stress" and harsh life circumstances, notably in urban settings and in phases of life when men were most vulnerable, namely as unmarried adults. The gender role put a great deal of pressure upon men regarding breadwinning, and in a time of little predictability, the urban life gave easy access to alcohol abuse and other shady activities. Death rates were especially high among middle aged men. ${ }^{12}$ Indeed, the phenomenon of "vulnerable men" has been noticed among some "uprooted" migrant groups as well, where the lack of social integration could endanger in particular young migrants' fragile new situation and lead to criminal and destructive behaviour. ${ }^{13}$ In some industrialized towns during the 19th century in Belgium, demographic research has shown distinct vulnerability also among settled married migrant men and their dependent families. ${ }^{14}$ Studies from the period of industrialization in two Swedish towns, Linköping and Sundsvall, also reveal divergent results pointing toward the importance of context. In Linköping, with small scale industry, there was a higher mortality among migrants compared to residents but in Sundsvall, with heavy indus-

9 Jan Lucassen and Leo Lucassen, "Migration, Migration History, History: Old Paradigms and New Perspectives", in Migration, Migration History, History: Old Paradigms and New Perspectives, eds., J. Lucassen \& L. Lucassen (Peter Lang, Bern, 1999), p. 9.

10 For a historiography of migration studies, see James Jackson Jr. and Leslie Page Moch, "Migration and the Social History of Modern Europe", in European Migrants: Global and Local Perspectives, eds., Dirk Hoerder \& Leslie Page Moch (Northeastern University Press, Boston, 1996), pp. 52-69.

11 Ibid., p. 63.

12 Jan Sundin and Sam Willner, "Social stress, socialt kapital och hälsa: Välfärd och samhällsförändring i historia och nutid", in Sambällsförändring och hälsa: Olika forskarperspektiv, eds., Jan Sundin \& Sam Willner (Institutet för framtidsstudier, Stockholm, 2003), p. 19, 40-43, 66. Sam Willner, Det svaga könet? Kön och vuxendödlighet i 1800-talets Sverige. Linköping Studies in Arts and Science, 203 (Linköping, 1999), p. 279f.

13 William H. Sewell Jr., Structure and Mobility: The Men and Women of Marseilles, 18201870 (Cambridge University Press, Cambridge, 1985), p. 221-233; J. Sundin and S. Willner, "Health and Vulnerable Men. Sweden: From Traditional Farming to Industrialisation", Hygiea Internationalis, vol. 4, no. 1 (2004), pp. 175-203. Quotation p. 194. [http://www.ep.liu.se/ej/ hygiea/].

14 Michel Oris and George Alter, "Paths to the city and roads to death: Mortality and migration in east Belgium during the industrial revolution", in Revue Belge d'Histoire contemporaine. Recent work in Belgian Historical Demography $19^{\text {th }}$ and early $20^{\text {th }}$ centuries, eds., I. Devos \& M. Neven (2001), p. 470, pp. 479-480, p. 487. 
try, there was instead a lower mortality among migrants. ${ }^{15}$ Hence, this field seems to need more research in order to understand a "complex" ${ }^{16}$ and comprehensive issue.

One methodological approach that seems to have been somewhat neglected in previous research on migration history, is qualitatively oriented studies. ${ }^{17}$ This allows an intensive analysis of a specific social and geographical context to be combined with an intensive analysis of the actual life histories of those who took part in this structural change. That approach has its roots in the life course analysis within the field of the history of the family where the lives of individuals are generally considered not to be adequately understood, unless the life history of the whole family is integrated. ${ }^{18}$ It could be particularly useful in migration history since it has a potential to bring together two major issues of theoretical concern: primarily the question of what strategies and resources migrants used (or lacked) to integrate and survive in new, supposedly stressful, situations and settings ${ }^{19}$ and secondly the general question of how family members or kin collaborated and reached out to each other during hard times and in different phases of life (referring to the "nuclear hardship hypothesis" ${ }^{20}$ and its

15 Sören Edvinsson and Hans Nilsson, "Swedish towns during industrialization”, Annales de Démographie Historique, vol. 2 (1999), pp. 63-96.

16 Ibid., p. 91.

17 This is also pointed out by Colin G. Pooley and Ian D.Whyte, "Introduction: approaches to the study of migration and social change", in Migrants, Emigrants and Immigrants: A Social History of Migration, eds., Colin G. Pooley \& Ian D: Whyte (Routledge, London \& New York, 1991), pp. 4-5; Colin G. Pooley and John C. Doherty, "The Longitudinal study of migration: Welsh migration to English towns in the nineteen century", in C. G. Pooley \& I. D. Whyte, eds. (1991), p. 143f. Qualitative data in the form of migrants' oral "life stories" have however been documented and discussed by Virginia Yans-McLaughlin, "Metaphores of Self in History: Subjectivity, Oral Narrative, and Immigration Studies" in Immigration Reconsidered: History, Sociology, and Politics, ed., Virginia Yans McLaughlin (New York \& Oxford, Oxford University Press, 1990), pp. 254-290. Quotation p. 254. Her postmodernistic approach can be compared with Tamara K. Hareven's more 'neopositivistic' approach in for example, T. K. Hareven, "What Difference does it make?", Social Science History, vol. 20, no. 3 (1996a), pp. 317-344; T. K. Hareven, "The generation in the middle: Cohort comparisons in assistance to aging parents in an American community", in Aging and generational relations over the life course: A historical and cross-cultural perspective, ed. Tamara K. Hareven (Aldine de Gruyter, New York, 1996b).

18 T. K. Hareven (1996a); T. K. Hareven, (1991), pp. 95-124. For a distinction of life course and family cycle, see T. K. Hareven, "Introduction: The Historical study of the Life Course", in Transitions: The Family and the Life Course in Historical Perspective, ed., T. K. Hareven (Academic Press, New York, 1978), pp. 1-16.

19 Leslie Page Moch, Moving Europeans: Migration in Western Europe since 1650 (Bloomington \& Indianapolis, 1992), p. 146. She stresses for example the function of social relations as important resources for the migrants. See also Dirk Hoerder, Cultures in Contact: World Migrations in the Second Millennium (Duke University Press, Durham \& London, 2002), p. 18.

20 For an argument on this, see Peter Laslett, "Family, kinship and collectivity as systems of support in pre-industrial Europe: a consideration of the 'nuclear-hardship' hypothesis", Continuity and Change, vol. 3, no. 2 (1988), pp. 153-175. For a somewhat modified interpretation, see Tamara K. Hareven, "Aging and Generational Relations: A Historical and Life Course Perspective", Annual Review of Sociology, vol. 20 (1994), pp. 437-461. 
critics $\left.^{21}\right) .^{22}$ Both questions thus touch upon a controversial theme in social history research regarding the role of the individual, family and the development of the modern social welfare state. ${ }^{23}$ In order to gain new and supplementary knowledge within this interdisciplinary area, it seems essential to synthesize demographic, social and family history data without omitting its closest context: the unique life history of each individual from which the data is derived. This requires a further downsized and scrutinized perspective and is the main reason for not performing a traditional demographic study from which statistical claims can be made. ${ }^{24}$ However, a qualitative life history study also deals with a great amount of data, but put together and stressed differently. Nevertheless, the actual point with this method is that a specific, and even unique, life history reveals in itself pieces of information on societal structures that can be exposed, but only if the life course is studied holistically and chronologically, and considered along with the individual's interconnections with family members and interpreted in close connection to a wider socioeconomic context. ${ }^{25}$ While doing this, the opportunity to learn something from the often neglected "private" life also reveals

21 See for example Barry Reay, "Kinship and the neighbourhood in nineteenth-century rural England: The myth of the autonomous nuclear family", Journal of Family History, vol. 21, no. 1 (1996), pp. 87-104; David I. Kertzer, "Household, History and Sociological Theory", Annual Review of Sociology, vol. 17 (1991), pp. 155-179; Muriel Neven, "The influence of the wider kin group on individual life-course transitions: results form the Pays de Herve (Belgium), 1846-1900", Continuity and Change, vol. 17, no. 3 (2002), pp. 405-435.

22 Compare the combination of issues brought up by Muriel Neven in "Terra Incognita: Migration of the Elderly and the nuclear hardship hypothesis", The History of the Family, vol. 8 (2003), pp. 267-295.

23 For examples of diverse opinions on this matter see respectively Barry Reay, "Kinship and the neighbourhood in nineteenth-century rural England: The myth of the autonomous nuclear family", Journal of Family History, vol. 21, No. 1 (1996), pp. 87-104 and David Thomson, "The welfare of the elderly in the past: A family or community responsibility?", in Life, Death, and the Elderly: Historical Perspectives, eds., Margaret Pelling \& Richard M. Smith (Routledge, London \& New York, 1991), pp. 194-221.

24 The approach in this study is partly stimulated by, but should not be conflated with, the several works in demographic research which perform life course analysis and analysis of family patterns, to name a few, see Lotta Vikström, Gendered Routes and Courses: The Socio-Spatial Mobility of Migrants in Nineteenth-Century Sundsvall, Sweden. Report no. 21 from the Demographic Data Base, Umeå University, 2003 (Umeå, 2003); Hans Nilsson and Lars-Göran Tedebrand, Familjer i växande städer: strukturer och strategier vid familjebildning i Sverige 1840-1940. Report no. 27 from the Demographic Database, Umeå University (Umeå, 2005); Martin Dribe, "Migration of rural families in $19^{\text {th }}$ century southern Sweden. A longitudinal analysis of local migration patterns", The History of the Family, vol. 8, (2003), pp. 247-265; Matteo Manfredini, "Families in motion: The role and characteristics of household migration in a $19^{\text {th }}$ century rural Italian parish", History of the Family, vol. 8 (2003), pp. 317-343; Ann-Kristin Högman, "Elderly migrants in a northern Swedish town in the nineteenth century", Continuity and Change, vol. 16 (2001), pp. 423-442.

25 See for example Nancy Green, "The comparative method and poststructural structuralism: new perspectives for migration studies", in J. Lucassen \& L. Lucassen, eds., Migration, Migration History, History: Old Paradigms and New Perspectives (Wien, 1999); T.K. Hareven (1991). 
itself. ${ }^{26}$ This procedure does not aim to create a representative picture, in a statistical sense, of the migrants. Rather, the approach lies in the intersection of the search for "typical" 27 and exceptional lives of human beings. A qualitative evaluation of a certain combination of particular facts, rather than aggregate numbers, is thus primarily needed.

The major ongoing study, which this paper is a first report from, includes a primary cohort of nineteen randomly selected migrant men from the lower social strata, in their family contexts. The men are selected after having moved to town, when they are in their forties. At this age, they are expected to stay in town. However, the procedure of selection also means that the men survived at least until their middle age. Furthermore, an extended cohort of totally 61 men, including the primary cohort, has also been constructed, based on all men who have been found in the same source matching the same selection criteria. The primary cohort thus consists of c. $30 \%$ of the whole cohort. $^{28}$

The life history analysis in the ongoing study is performed in a stepwise process. ${ }^{29}$ In the particular phase, which is dealt with in this paper, a qualitative 'inventory' is made, aiming to discern certain "migrant profiles" ${ }^{30}$, and understand what kind of life

26 See for example Donna Gabaccia, "The Transplanted: Women and Family in Immigrant America”, Social Science History, vol. 12 (1988), pp. 243-253.

27 J. Sundin and S. Willner (2003), p. 48.

28 The extended cohort, including the primary, consists of all men (61) in the lower social strata who were born 1800-1802, elsewhere than Linköping but living in that town (i.e. noticed in the church books called Husförhörslängder) at some point during the registration period 1840-1845. This means that they have previously moved into town. The analysis of the family context is limited to the primary cohort, and includes the men's wives and children as well as the spouses' parents and siblings and they are followed from the perspective of the primary cohort men and their spouses. The lower social strata is defined as consisting of "craftsmen without the master title, journeymen and apprentices, maids and farmhands, workers, paupers, widows, wives and fiancées, sons, daughters, servants, seamen, small scale tradesmen, mongers, crofters, widowers, not stated/readable", in accordance with Hans Nilsson's classification in Mot bättre hälsa: Dödlighet och hälsoarbete $i$ Linköping 1860-1894 (Linköping, 1994), p. 49. However, two exceptions from Nilsson's scheme have been made. Craftsmen with a master title as well as owners of buildings/ town houses (gårdsägare) have been included since these titles are proven to be in a grey area which could be of interest in a qualitative study like this. The extention of the cohort is constructed for reference purposes in order to build a kind of background with basic micro demographic information on the whole cohort. The extension was made after the random selection of the primary cohort.

29 The main areas of interest involve the migrants' social, cultural and geographical backgrounds, "culture of mobility", (according to Börje Harnesk, Legofolk: drängar, pigor och bönder $i$ 1700- och 1800-talens Sverige (Umeå, 1990), p. 166), livelihood, housing arrangements, social resources (on an individual and structural level), the use of family bonds, gender and "social roles" (according to Johannes Siegrist, "Place, social exchange, and health: proposed sociological framework", Social Science and Medicine, vol. 51 (2000), pp. 1283-1293), opportunities for social integration, social mobility and emancipation, life events and social, demographic and health characteristics. These life circumstances are interpreted in close connection to the life courses and circumstances of the rest of the family.

30 This term has been borrowed from C. G. Pooley and J. C. Doherty (1991), p. 148. The method in their study is not identical with the method in this paper, but the intentions are similar. 
courses actually were possible regarding life events and social and demographic characteristics. It means that the life histories of the primary cohort, consisting of the nineteen migrant men in their family context, are categorized. The first results derived from this procedure and presented in this paper concern a subgroup of nine men found to have a hard time in town. Their 'misery' state has been qualitatively categorized from an estimation of their overall life and health circumstances primarily post migration to the town with a slight emphasis on the end of the migrants' lives. Different kinds of 'problems' (in a wide, but severe sense) to carry on, and cope, with their lives, have been identified and acknowledged. The basis for the evaluation is the men's lives, and hence their lives will be compared to the partly intertwined life courses of their wives. A gender perspective has motivated the focus on men, since their roles seem to be exposed to certain risks in the transitional society. ${ }^{31}$ Since the husbands had the role of family providers, their wives could be expected to share the problems found. However, the awareness of gender roles makes it theoretically risky to take for granted that the wives shared exactly the same experiences as their husbands. ${ }^{32}$

The main sources in the study are church registers, which in Sweden can be used for tracking individuals on a micro level, obtaining information about the individual's livelihood, conduct and health status. The intention was to cover these migrants' lives as detailed as possible but certain information was not within the range of the database which was used. ${ }^{33}$ This meant that a manual search was added, predominantly on the sources covering the individuals' backgrounds. ${ }^{34}$ Although the ambition was to be systematic, some information was just not available due to problems of finding the individuals. This time-consuming, but rewarding, work is however not yet completed.

31 The gender roles are viewed as giving "positive rights" and "negative rights", according to Sheila Ryan Johansson, "Welfare, Mortality, and Gender. Continuity and Change in Explanations for Male/Female Mortality over three Centuries", Continuity and Change, vol. 6, no. 2 (1991), pp. $135-177$.

32 See for example D. Gabaccia (1988), pp. 243-253.

33 Information on the migrants are followed backwards and forwards from the selection point of Linköping. The database is called Linköpings historiska databas (LHD), and is designed in cooperation with the Demographic Database in Umeå, Umeå university (DDB). DDB originally created the data base and owns the information. The database covers sources from the town of Linköping and 26 parishes around Linköping in the county of Östergötland. Moreover, DDB has an Internet-based database called INDIKO [http://www.ddb.umu.se/indiko/index.html], which contains church registers from another nine parishes around Linköping in Östergötland (and more than 30 other parishes). These two databases have a common ground with the exception that INDIKO does not convey information about the priests' notifications on their congregation members. Since this information is of importance to this study, INDIKO is only used in a complementary manner.

34 The Swedish church registers are available on the Internet, through Genline [http://www.genline.com/], a service for genealogical purposes which provides scanned microfilm of the original sources. These micro films were originally produced for and by the Mormons in Salt Lake City, Utah, USA and are kept at the Swedish National Archives in Stockholm. Genline's distribution of scanned church registers is an ongoing project. In some cases micro cards, which derive from the microfilms, also kept at the Swedish National Archives and distributed by SVAR, have been studied to fill some gaps of information on individual life courses. 
When indicated, other sources were also consulted, for instance hospital journals, criminal records and records of poor relief for the purpose of getting as rich a picture as possible of the migrants' destinies. These 'other sources' will be further explored in the major, ongoing study, since previous research indicates that they could add to a modified and nuanced picture of migrant destinies. ${ }^{35}$

\section{The Situation and Setting of Linköping During the First Half of the 19th Century}

The context under study is the town of Linköping in the county of Östergötland, in the south east of Sweden, during the first half of the 19th century. It was a small town with approximately 3,000 inhabitants in the first decade of the century. ${ }^{36}$ In the middle of the century, the population had grown to approximately 5,000 inhabitants. ${ }^{37}$

At this time, only about $10 \%$ of the total population in Sweden lived in towns. ${ }^{38}$ Yet, previous studies reveal that the migratory pressure on the town was quite heavy, but most of the migrants did not stay in town for more than a few years. In 18211830 for example, 361 persons moved in to Linköping, while 312 moved out (annual mean). ${ }^{39}$ Still, the migrants were in majority in Linköping. In 1862, only $37 \%$ of the population was born in Linköping. ${ }^{40}$ This had to do with a lack of natural increase, due to high mortality despite high fertility. ${ }^{41}$ The lack of natural increase was paralleled in all towns in Sweden before the 1840s. ${ }^{42}$ In Linköping in 1821-1830, there were 34.7 deaths per thousand (annual mean). ${ }^{43}$ There were however, huge gender differences. In 1815-1849, male mortality per thousand, ages 25-49, was 25.1 and for women 13.8. Such a large difference cannot be found in the surroundings of Linköping. ${ }^{44}$ There was an increase of male adult mortality during the first half of the

35 See L.Vikström (2003), pp. 268-270.

36 In 1805, there were 2915 inhabitants in Linköping, according to statistics from Tabellverket, digitalized by DDB, Umeå University [http://www.ddb.umu.se/visualisering/Tabverk/ FormF320].

37 In 1850, there were 5240 inhabitants in Linköping, according to statistics from Tabellverket, digitalized by DDB, Umeå University [http://www.ddb.umu.se/visualisering/Tabverk/ FormF520].

38 Bo Öhngren, "Urbaniseringen i Sverige 1840-1920", in Urbaniseringsprosessen i Norden, del 3. Industrialiseringens forste fase, ed., Grethe Authén Blom (Universitetsforlaget, Oslo, 1977), p. 271.

39 Folke Lindberg, Linköpings Historia 3. 1576-1862 Sambälls- och kulturliv (Linköping, 1976), p. 14.

40 Hans Nilsson and Sam Willner, Inflyttare till Linköping under 1800-talet. Rapport no. 6, Centrum för lokalhistoria i Linköping (Linköpings universitet, 1994), p. 6.

41 F. Lindberg (1976), p. 14.

42 B. Öhngren (1977), p. 279.

43 F. Lindberg (1976), p. 15.

44 S. Willner (1999), p. $59 f$. 
century in Linköping, which has been interpreted as a probable influence of migration by rural proletarians. ${ }^{45}$ This made the population of Linköping quite proletarian in its character. Despite that, the town was an educational and ecclesiastical centre. Expenses for poor relief were high. In 1836 poor relief was handed out to every 21st person in town. ${ }^{46}$ The large expenses made the committee for poor relief worried, for instance, about the military musicians' company to settle in Linköping because of the expected burden put upon poor relief. ${ }^{47}$ Most migrants had their origin in the nearest surroundings of the town and left an agrarian way of living for whatever job opportunities they could find in town. The majority were young and unskilled maids and farmhands. ${ }^{48}$ They met a town based primarily on craft, supplemented by manufacture and agriculture. ${ }^{49}$

How these migrants managed, mortalitywise, in Linköping is only known for the period of industrialization. In a five year follow-up, during the years 1880-1885, mortality among migrants was found to be about $25 \%$ higher compared to the general mortality in town. This was in spite of the migrants' low age and when the migrants are compared to the same ages, their higher mortality is even more distinct. ${ }^{50}$ The conclusion is that these migrants to Linköping seem to have been more likely to get infections, because of their previous residences in healthier environments. Knowledge about how health was influenced by the duration of time living in town could be of complementary value. ${ }^{51}$ The question of any migrant-specific social conditions in this case cannot be ruled out either but it is harder to capture at an aggregate level.

\section{Migrant Men in Misery}

Nine of the nineteen men in the primary cohort confronted obvious problems and harsh life circumstances in town. To understand these men's lives, it is of interest to know what went wrong in their lives, in what life phases and locations it took place and if or how the misfortunes can be related to gender. This "migrant profile" is first illustrated by Sven and his wife Stina whose life courses are thoroughly explored

45 Ibid., p. 85.

46 F. Lindberg (1976), pp. 70-71.

47 J. P. Tollstorp, Beskrifning öfver Linköping (Föreningen gamla Linköping, Linköping, 1957, orig. 1834), p. 166.

48 Hans Nilsson, Mot bättre hälsa: Dödlighet och hälsoarbete i Linköping 1860-94. Linköping Studies in Arts and Science, 105 (Linköping, 1994), p. 84.

49 Mats Hellspong, "Städer", in Land och stad: Svenska sambällen och livsformer från medeltid till nutid, eds., Mats Hellspong \& Orvar Löfgren (Gleerups, Malmö, 2001), p. 205.

50 H. Nilsson (1994), p. 187. See also Sören Edvinsson and Hans Nilsson, "Swedish towns during industrialization", Annales de Démographie Historique, vol. 2 (1999), pp. 63-96, where the same results are presented and compared to results from the town of Sundsvall.

51 S. Edvinsson and H. Nilsson (1999), p. 81, 91f. 
below. Further, and briefer, examples of the other men's life courses will follow as well as comparisons with their wives' life courses.

\section{An Explorative Example of Sven and Stina}

Sven Persson, ${ }^{52}$ was born in the parish Wardnäs as a son of a farmer. His father owned the farm and his mother was herself a daughter of farmers. When Sven was about five years old his parents got divorced, which was a rare event in those days, especially in the countryside. ${ }^{53}$ His mother moved away and after a short while the whole family was dispersed. However, Sven reunited with his mother on his grandparents' farm. When he was nine years old he got a stepfather who probably kept the farm of Sven's grandparents. Four years later his stepfather died and Sven was left again without a father. Two years after that he was fifteen and left home to begin to work as a farmhand. According to David Gaunt, Sven now entered his "lost years" 54 , a kind of "limbo" state of life when the servants were not old enough to get married but old enough to work hard in someone else's household. ${ }^{55}$ This period coincides with a "culture of mobility" among servants, a concept stated by Börje Harnesk who interprets the servants' frequent moves as a sign of struggle for emancipation. ${ }^{56}$ Before Sven moved to Linköping in 1826 he had changed residence and employer at least five times. When he was in his twenties, he had already experienced problems with his knees, which hindered him in working and paying his taxes. When he entered Linköping 27 years old, he had however been recovered for several years. In town he continued working as a farmhand ${ }^{57}$ but he did not stay in Linköping more than one year. He then returned to the countryside for farmhand work and ended up with his sister who was married to a farmer. He only stayed there for a few months before he decided to leave them to work in a different parish and a different household. This turned out to be a crucial decision since he met his wife to be, Stina Sophia Jonsdotter, ${ }^{58}$ born in Slaka, in the new household where she worked as a maid. As a daughter

52 Sven Persson was born 17991110 in Vårdnäs, according to Genline, födelseboken för Vårdnäs 1799, vol. C: 3, p. 100. However, according to DDB/LHD, husförhörslängderna för Linköpings Domkyrkoförsamling, 1841-1845 (i.e. point of selection), he was born 18001112. This circumstance has not been considered to disqualify him from the cohort.

53 Marja Taussi Sjöberg, Skiljas: Trolovning, äktenskap och skilsmässa i Norrland på 1800-talet (Författarförlaget, Stockholm, 1988), p. 68, 171, table 1.

54 David Gaunt, Familjeliv i Norden (Gidlunds, Stockholm, 1983), p.114.

55 Ibid., p. 22.

56 B. Harnesk (1990), p. 166.

57 The terms farmhand (dräng) and maid (piga) are also used for unmarried men and women, which makes it hard to know for sure what occupation they had, see B. Harnesk (1990), p. 173.

58 Stina Sofia Jonsdotter was born 1805-01-30 in Slaka, according to Genline, födelseboken för Slaka 1805, vol. C: 3, p. 224. 
of crofters she had left her parents when she was 20 years old. Her family advanced to be owners of a piece of land after she had moved away.

Stina and Sven got married within a year after Sven's arrival in the household. The bride was 23 years old and the bridegroom was 29. They had a son $31 / 2$ months after the wedding ceremony, which reveals a premarital conception. Their son was born and baptized in the parish where Sven's mother and a stepsister lived. The boy stayed for seven months with Sven's mother and stepsister where Sven had lived as a child. It seems likely that Stina had to go to Sven's mother to give birth to the child since this was not allowed to happen within their employer's household. A while after their marriage, they moved to another place. Since married couples were not usually hired within a farmer's household, Sven soon started to work as a labourer at a farm, while having his own household (statdräng). Stina was supposed to work as well, milking the cows. Such working and living conditions are known to have been harsh and characterized by frequent moves between different employers. ${ }^{60}$

In 1833 the family, now extended with a one year old daughter, moved to Linköping a second time. Would this stay be permanent or would he and his family keep on moving every second or third year as they have been doing so far? If they stayed, how did they manage to settle in town and make a living? What continuities and discontinuities would there be compared with their former way of living? What strategies could they use to better their lives or at least get by?

Sven continued working as a statdräng in Linköping. They got another son who died when he was eight months old from "aches in the stomach" ("magplagor"), a diagnosis which can be related to sanitary insufficiencies, worsened by summer heat and, often, the lack of protective breastfeeding. ${ }^{61}$ Next year, Sven started working as an unskilled worker (arbetskarl), a vague but common term for any kind of manual work. The family got another daughter and the eldest son began school when he was 8-9 years old. 1839 they had one more son and the following year Sven was hired to work for the mayor in Linköping.

Until now, Sven and his family appear to have been able to get by, but in the beginning of the 1840 s they reached a turning point. A daughter was born but died

59 According to Christer Winberg, Folkökning och proletarisering: Kring den sociala strukturomvandlingen på Sveriges landsbygd under den agrara revolutionen. Meddelanden från Historiska institutionen i Göteborg (Göteborg, 1975), p. 39, 42, 45, there was a grey area between different social categories during this period of time in the agrarian society. Stina's parents are illustrating the difficulties when it comes to distinguish the propertied classes from others.

60 Sten Carlsson, Yrken och sambällsgrupper: Den sociala omgrupperingen i Sverige efter 1866 (Almqvist \& Wiksell, Stockholm, 1968), pp. 53-56.

61 Anders Brändström, "De kärlekslösa mödrarna": Spädbarnsdödligheten i Sverige under 1800talet med särskild hänsyn till Nedertorneå. Umeå Studies in the Humanities, 62 (Umeå, 1984); Magdalena Bengtsson, Det hotade barnet:Tre generationers spädbarns- och barnadödlighet i 1800-talets Linköping. Linköping Studies in Arts and Science, 145 (Linköping, 1996), p. $160 f$. 
from "sudden death" ("Slag") four months later. ${ }^{62} 15$ months after her birth a son was born. After his first birthday the boy and Stina were hospitalized for having a venereal disease. They stayed three months at the hospital, called Kurhus, ${ }^{63}$ a hospital or hospital department reserved for patients with venereal diseases developed in order to isolate the sick while curing them. ${ }^{64}$ The medical doctor concluded that Stina had been "infected by her child" who in his turn had been "infected by a woman [---] who had breastfed the child." "This could indicate a vulnerable social situation because syphilis (syfilis) was known to be spread between wet nurses and children or between foster children and their foster families. ${ }^{66}$ However, this kind of transmission was not reported by the medical doctor in Linköping that year. ${ }^{67}$ Even if Stina did not leave her son to a wet nurse because this was more of an upper-class habit, she might have left him to someone for temporal care who might have infected him. It is not unlikely that such a care included breastfeeding since this was not taboo in these days. ${ }^{68}$ If Sven and Stina were not integrated in town, this could mean that they had to leave their child with unscrupulous or socially exposed individuals. ${ }^{69}$ The strained situation is further confirmed when Sven's ability to support the family is considered. He was left alone with four children to support and take care of at the time his wife fell ill and their first born son had moved away. By now, the priest noticed that he was "poor". ${ }^{70}$ Their youngest son died two years old, probably not fully recovered from syphilis,

62 The diagnosis "Slag" meant sudden death among infants and children. It can often be related to diarrhoea and dehydration in the beginning of the nineteenth century Linköping, according to M. Bengtsson, "The Interpretation of Cause of Death Among Infants", Hygiea Internationalis, vol. 3, issue 3 (2002), p. 53-73. [http://www.ep.liu.se/ej/hygiea/].

63 DDB/LHD, husförhörslängd för Linköpings Domkyrkoförsamling 1841-1845, vol. 37, p. 348; Hospital record from Lasarettet i Vadstena, Överläkaren, Journal vid Wadstena Curhus, 1844. D1a25. Patient No: 97 and No: 98. Landstingets arkiv i Östergötland.

64 Rolf A. Gustafsson, Traditionernas ok: Den svenska hälso- och sjukvårdens organisering $i$ historie-sociologiskt perspektiv (Esselte studium, Solna, 1987), p. 292.

65 Hospital record from Lasarettet i Vadstena, Överläkaren, Journal vid Wadstena Curhus, 1844. D1a25. Patient No: 97 and No: 98. Landstingets arkiv i Östergötland.

66 Nils Thyresson, Från franzoser till Aids: Kapitel ur de veneriska sjukdomarnas historia i Sverige (Carlssons, Stockholm, 1991), p. 96; C. A. Rosborg, Årsberättelse från Provinsialläkare, 1860 i Trosa. Medicinalhistorisk databas, Medicinalstyrelsen, RA/420177.03. Rapport 90/181, Diarienummer 1220/61, vol. SK:30. [http://www.2.histstud.umu.se/dokument/provlak/1860/ p8600488.htm] 2005-01-19.

67 L. Lindgren, Årsberättelse från Provinsialläkare 1844 i Linköping. Vård- och omsorgshistorisk databas. Medicinalstyrelsens föregångare/Sundhetskollegium, RA/420177.03, Rapport 22/90, Diarienummer 1453/1845, vol. 14. [http://www.2.histstud.umu.se/dokument/ provlak/1844/p8440580.htm] 2005-01-19.

68 Susanna Hedenborg, "To breastfeed another woman's child: wet-nursing in Stockholm, 1777-1937", Continuity and Change, vol. 16, No. 3 (2001), pp. 399-422, p. $412 f$.

69 It must be added, however, that venereal disease was frequent among poor people, see Anna Lundberg, Care and Coercion: Medical Knowledge, Social Policy and Patients with Veneral Disease in Sweden 1785-1903. Report no. 14 from the Demographic Database (Umeå, 1999).

70 DDB/LHD, Husförhörslängden för Linköpings Domkyrkoförsamling 1841-1845, vol. 37, p. 348. 
from "sudden death" ("slag"), like his sister had done two years earlier. Sven was pauperised and died seven months later, 47 years old from Wasting ("Tärande") disease. This means that he was suffering from a chronic degenerative illness, often cancer or tuberculosis. ${ }^{72}$ From the diagnosis it can thus be assumed that Sven had been sick for a while which might have urged Stina to leave the children to someone else while working.

Stina was hereafter a widow living on poor relief, left alone with three children between seven and fourteen who left home when they were 15, 17 and 18 respectively. When the eldest son came back from Stockholm 1853, he had become a shoemaker and was soon able to marry a girl from Linköping. When he moved to start a family of his own in town, Stina went along. She lived with her son's family for the next few years. Her son bought a house in town where he established himself as a shoemaker which was a social advancement. It seems like he had capacity to help his mother because she was no longer registered as pauperised. Research from a similar milieu, the town of Örebro, shows that most households could not afford cohabiting with old parents. ${ }^{73}$ From a gender perspective it is told to be rare too since in most cases the caring burden was put upon the women. ${ }^{74}$ Yet, when Stina was 58 years old, and seemingly in a quite stable social position, she moved to Gothenburg, a city more than 300 kilometres away. By now she had lived 17 years without Sven, and 30 years in Linköping. What was behind this decision? People who had been treated for venereal disease were slightly overrepresented when it came to long distance moves within the country, but aside from that they showed no specific signs of marginalisation in society. ${ }^{75}$ Her move was instead most likely caused by the fact that her daughter had previously moved to the same city. ${ }^{76}$ It is not presumable that women moved far away without any connections at all at the destination. ${ }^{77}$ Stina died when she was 59 years old in Gothenburg, one year after she had left Linköping. ${ }^{78}$

71 DDB/LHD, Dödboken för Linköpings Domkyrkoförsamling 1846, vol. 609, p. 247. He died on the 25 th of January, which means he would not turn 47 until November. However, in this study only the calendar years have been considered in the calculation of age etc. See table 1.

72 S. Willner (1999), p. 310; J. Sundin (1999), p. 100.

73 Elsa Lunander, "Bland handlare och hantverkare i en svensk landsortsstad under 1800talet: Om hushåll och familjestruktur i Örebro", in Den utsatta familjen: Liv, arbete och samlevnad $i$ olika nordiska miljöer under de senaste två hundra åren, ed., Hans Norman (LTs förlag, Stockholm, 1983), p. 157.

74 Iréne Artæus, Kvinnorna som blev över: Ensamstående stadskvinnor under 1800-talets första hälft-fallet Västerås. Studia historica upsaliensia, 170 (Uppsala, 1992), p. 100.

75 A. Lundberg (1999), p. 137, 144.

76 DDB/LHD, Husförhörslängden för Linköpings Domkyrkoförsamling, vol. 50, p. 222; Utflyttningslängden för Linköpings Domkyrkoförsamling, vol. 406, p. 0331.

77 I. Artæus (1992), p. 88, 101.

78 The cause of death is not known. The fact that she is supposed to have died at the same day she arrived in Gothenburg is telling something about the muddy circumstances around her. Genline, Göteborgs Gustavi domkyrkoförsamling, husförhörslängd 1861-1865, AIA:9. Förteckning över inflyttade ogifta personer vid Gustavi Domkyrkoförsamling 1861-1865. 
First of all, both Sven and Stina were migrants, but when their life courses are compared, certain differences appear. Sven moved to Linköping twice. The second time he stayed for the rest of his life. Stina moved to Linköping once but left town after more than 30 years. This information underlines the often requested need of a more nuanced way of interpreting migratory behaviour than which has normally been the case, because both Stina and Sven contributed to different migration types over their life course. In aggregated surveys this is hidden, putting us at risk of assuming that different individuals always participate in different types of migration. Furthermore, Sven's and Stina's migratory behaviour clearly shows the need to interpret the individuals' life courses in close connection to life courses of other family members or kin, since motives for migration can be revealed.

When Sven's and Stina's lives are compared, gender roles seem to influence their partly different life events. Stina lived 13 years longer than Sven, and after their shared life crisis she survived another 18 years despite her risky situation as a widow with children to take care of. ${ }^{79}$ Stina's childhood and youth was however more stable than Sven's. If her life course is considered, the most crucial phase of life seems to have been the parenting stage, while living in town married to a sick provider with a lost ability to support his family. To fully understand how this critical situation was coped with, Stina's and Sven's different gender and social roles must be connected to their available social resources, as well as generational relations. This will be dealt with in further steps in the analysis, beyond the direct scope of this paper. Here, some additional examples of migrant men with a similar life pattern will be shown.

\section{Extracts from Migrant Life Courses: Childhood and Adolescents}

Johannes Tollsten, ${ }^{80}$ was born in Sankt Lars, a parish nearby Linköping. His father was a crofter and a tailor. Johannes' mother died when he was three years old and he got a stepmother when he was four. At age fourteen he became an apprentice in his sister's household since she was married to a tailor. Peter Ericsson, ${ }^{81}$ was born in Västerlösa and was brought up in a soldier's croft. When his father resigned from the army Peter was 12-13 years old and they moved to a small and simple cabin called backstuga. His father died when he was sixteen but by then Peter had already moved away in order to work. Shortly after, he returned and since he was "small" and "weak", he was consid-

79 The exposed situation of widows are wellknown, for an overview of this research field within a wider context of the household and the family, see Michel Oris and Emiko Ochiai, "Family Crisis in the Context of Different Family System: Frameworks and Evidence on 'When Dad Died'", in When Dad Died: Individuals and Families Coping with Distress in Past Societies, eds., Renzo Derosas \& Michel Oris (Peter Lang, Bern, 2002), pp. 17-79.

80 Johannes Tollsten was born 18000409 in Sankt Lars, according to DDB/LHD, födelseboken för Sankt Lars, vol. 305, p. 93.

81 Peter Ericsson was born 18000824 in Västerlösa, according to Genline, födelseboken för Västerlösa 1800, vol. C: 4, p. 9. 
ered "unable to work". He kept moving back and forth to his mother who was "destitute". Johan Carl Stenqvist, ${ }^{83}$ was born in Landeryd. He was an illegitimate child with an "unknown" father. His mother got married the year after Johan's birth and they settled in Sankt Lars. His stepfather was a farmhand and they lived in a backstuga but soon he became "ill" and got "blind", ${ }^{84}$ not being able to support his family and receiving poor relief. ${ }^{85}$ It was not unusual that unmarried women with children were thrown to the 'leftovers' at the marriage market. ${ }^{86}$ The new husband died when Johan was ten years old. Johan's mother was pauperised and got into trouble with the law. ${ }^{87}$ Two years later, she married once again, this time with a day labourer and statdräng who drowned three years later.

Johan Zettergren, ${ }^{88}$ was born in Asker as the son of the village smith. When Johan was around 10, the family moved from the village and his father, as time went on, settled as a crofter. ${ }^{89}$ When Johan was 17 years old he left his parents, who both still lived, and went to the town of Örebro to work as an apprentice to become a tailor. ${ }^{90} \mathrm{~A}$ couple of years later, he was engaged to be married (trolovadlforlovad). His first son was born 1822 and a couple of months later Johan married his wife as he had become a journeyman (gesäll). Johan and his family moved to another town, Askersund, two years later, where he became a master. Here, Johan was "accused of theft", according to the priest's notification. ${ }^{91}$ Lars Petter Zetterström, ${ }^{92}$ was born in Rönö where his father was a tailor and a crofter, like Johan Tollsten's. However, his background differs from the others because his parents survived his childhood, he had good grades when the priest examined his skills in reading and catechism and he was put in school in the nearby small town, Söderköping, when he was thirteen years old. When he was seventeen he went to the city of Stockholm but returned one year later to his parents'

82 Genline, Västerlösa husförhörslängder, vol. A1:6, p. 32 and A1:7, p. 30.

83 Johan Carl Stenqvist was born 18020113 in Landeryd, according to DDB/LHD, födelseboken för Landeryd, vol. 303, p. 107.

84 DDB/LHD, Husförhörslängden för Sankt Lars församling, vol. 4, p. 66.

85 Genline, Dödboken för Sankt Lars församling 1812, vol. C1:5, p. 359.

86 Marja Taussi Sjöberg, Dufvans fängar: Brottet, straffet och människan i 1800-talets Sverige (Författarförlaget, Stockholm, 1986), p. 30.

87 DDB/LHD, Husförhörslängden för Sankt Lars församling, vol. 5, p. 70. Johan Carl's mother had, most likely, been accused of theft. The Swedish expression was "Stått tjufvrätt".

88 Johan Zettergren was born 18010214 in Örebro, Asker, according to Genline, födelseboken för Örebro Asker, vol. C:3, 1783-1811. GID 284.59.38300.

89 Genline, Närke och Värmland: Örebro Norrbyås Husförhörslängd, vol. A1:11, 18111816. GID 201.28.23700.

90 Genline, Närke och Värmland: Örebro Norrbyås Husförhörslängd, vol. A1:12, 18161820. GID 201.29.35300; Örebro stad, Inflyttningslängd 1818-1820, vol. A1:16B GID 2316.102.66300; Örebro stad, Husförhörslängd, vol. A1:17A, 1821-1825 GID 2316.103.78500.

91 Husförhörslängd för Askersunds stadsförsamling, AI:7, 1816-1825, p. 243 and 281 (Microcard, SVAR: No 16314, card 6/7); In- och utflyttningslängd för Askersunds stadsförsamling 1824 and 1825, B:1 1822-1835 (Microcard, SVAR: No 16318, card 2/3 and 3/3).

92 Lars Petter Zetterström was born 1802-08-01 in Rönö, according to Genline, födelseboken, vol. C1: 1, p. 336. 
croft. Johan Henric Petterson, ${ }^{93}$ also had a different childhood. He was born in Bjälbo as a son of an organist and bell ringer. ${ }^{94}$ The holder of such an occupation did not belong to the lowest social strata and had educational tasks among the population. ${ }^{95}$ However, Johan's father died when Johan was eleven years old and his mother died when he was seventeen. Both parents died from "consumption". "This diagnosis is related to social circumstances, especially housing and working conditions and could, like wasting disease, be prolonged in its course. ${ }^{97}$ The eldest brother took over the work as organist when their father died. Johan lived with his brother's family before he left home when he was about twenty years old. ${ }^{98}$ Peter Persson, ${ }^{99}$ was born in Vreta Kloster, but any information on his childhood is unavailable. The earliest information about him dates to his twenties, when he was working as a farmhand in the parish of Kaga. When he was 27 years old he moved to the parish Sankt Lars, nearby Linköping, where he, 29 year old, met his wife. ${ }^{100}$ Johan Edoff, ${ }^{101}$ was born in Sund. He was an illegitimate child of a maid who had failed to make the father acknowledge the fatherhood. His siblings had the same status. They lived in a cabin as lodgers and the mother was "poor". She took care of her mother who was "destitute" and "sickly". Johan left home before he was eighteen years old. ${ }^{102}$

When studying these migrant men's upbringing and youth, it becomes evident that in almost all cases, they had faced problems before they entered Linköping. Several of the migrant men in this group were sons of proletarians, yet the demarcation line between different agrarian social groups is not always easy to define. ${ }^{103}$ Their socioeco-

93 Johan Henric Pettersson was born 18021024 in Bjälbo, according to Genline, födelseboken för Bjälbo, vol. C: 2, p. 385.

94 Genline, Födelseboken för Bjälbo församling 1802, vol. C:2 1772-1827, p. 385.

95 S. Carlsson (1968), p. 168f. Johans mother was called "madame“, which according to S. Carlsson (1968), p. 278, was a title no longer used among the uppermost classes but neither used among proletarians.

96 Genline, Dödbok för Bjälbo församling, 1813 and 1819.

97 B-I Puranen Tuberkulos: En sjukdoms förekomst och dess orsaker. Sverige 1750-1980. Umeå Studies in Economic History, 7 (Umeå, 1984), p. 346f.

98 Genline, Husförhörslängderna för Bjälbo församling, vol. A1:6, 1810-1820, p. 67, p.21 and vol. A1:7, p. 31 (It is difficult to make out, due to handwriting, the exact year when Johan left home.)

99 Peter Persson was born 1802 in Vreta Kloster, according to DDB/LHD, husförhörslängderna för Linköpings Domkyrkoförsamling, vol. 37, p. 358. This can not be confirmed, due to doubt on who his parents were. There are several Peter born in the parish, who are candidates.

100 DDB/LHD, Husförhörslängden för Kaga, vol. 2, p. 56; utflyttningslängden för Kaga, vol. 403, p. 55; inflyttningslängden för Sankt Lars, vol. 203, p. 21; husförhörslängden för Sankt Lars, vol. 10, p. 221; husförhörhörslängden för Sankt Lars, vol. 12, p. 227; husförhörslängden för Sankt Lars, vol. 12 , p. 238.

101 Johan Edoff was born 18020219 in Sund, according to Genline, födelseboken 1802, vol. C: 5 , p. 118.

102 Genline, Födelseboken för Sund, 1802, vol. C:5 1793-1852, p. 118; Husförhörslängden för Sund, vol. A1:3 1805-1813, p. 105; Husförhörslängden för Sund, vol. A1:4 1813-1819, p. 32; Husförhörslängden för Sund, vol. A1: 5 1820-1824, p. 51.

103 C. Winberg (1975), p. 39, pp. 42, 45. 
nomic background was however shared by most of the migrants who headed towards the town. Sven, Johannes, Peter E., Johan Carl and Johan E. did, in addition, experience a childhood in despair. Their homes were split up, pauperised and marked by sickness. Even in cases when the social belonging was somewhat better, like Johan Henric's, problems can be seen. Growing up without both parents could be risky for a child, with different ramifications if it was the mother or the father who deceased. ${ }^{104}$ Children over five years at the time of a parent's death had a better prognosis compared to younger children. Interestingly, if the child survived childhood, studies have shown an upward social mobility among them which was not paralleled among other children. ${ }^{105}$ However, split homes, poverty and social misery are also backgrounds common to children who became criminals later in life. ${ }^{106}$

When Lars Petter, Johan Z and Peter P. are concerned, their problems, given what is known, seems to have started somewhat later in life, after arrival in town. This migrant exposé now turns to what happened to this group of migrant men after they entered town.

\section{Extracts from Migrant Life Courses: Settlement in Town}

To start with, an overview is constructed showing the migrant men's status of occupation/livelihood on three occasions in life: right before entering town, in their forties (point of selection) and prior to death along with age of marriage, years spent in Linköping, their age at death and cause of death.

All of these men died in Linköping. Johannes, Lars and Johan Henric died from wasting disease as Sven did. Johan Z. died from alcohol abuse and Johan Carl died from dropsy, which is a disorder known to be related to alcohol abuse, malnutrition or organ dysfunction. ${ }^{107}$ Peter E. reached old age but since he had been sick and without means for a long time before he died, his life should be considered together with this group of men. Peter P. and Johan E. were even older when they died but, as Peter E., they had been poor for a long time. There are no signs of upward social mobility even

104 See for example, Erik Beebink, Frans van Poppel and Aart C. Liefbroer, "Parental Death and Death of the Child; Common Causes or Direct Effects?", in When Dad Died: Individuals and Families Coping with Distress in Past Societies, eds., Renzo Derosas \& Michel Oris (Peter Lang, Bern, 2002), p. 258-260; Marco Breschi and Matteo Menfredini, "Parental Loss and Kin Networks: Demographic Repercussions in a Rural Italian Village”, in eds., R. Derozas \& M. Oris (2002), p. 382-387.

105 Sune Åkerman, Ulf Högberg and Tobias Andersson, "Survival of Orphans in NineteenthCentury Sweden", in Orphans and Fosterchildren: A Historical and Cross-Cultural Perspective, ed., Lars-Göran Tedebrand, Report No. 11 from the Demographic database (Umeå, 1996), p. 85, 89-90.

106 M. Taussi Sjöberg (1986), p. 36.

107 See for example, S. Willner (1999), p. $309 f$. 
Table 1. Migrant men in misery: status of occupation/livelihood on three occasions in life: right before first moving into town, in their forties (point of selection) and prior to death along with age of marriage, years spent in Linköping and their age at death and cause of death.

\begin{tabular}{|c|c|c|c|c|c|c|c|}
\hline $\begin{array}{l}\text { Migrant } \\
\text { ID }\end{array}$ & $\begin{array}{c}\text { Before } \\
\text { entrance }\end{array}$ & $\begin{array}{l}\text { In the } \\
\text { forties }\end{array}$ & Prior death & $\begin{array}{c}\text { Age of } \\
\text { marriage }\end{array}$ & $\begin{array}{l}\text { Years spent in } \\
\text { Linköping } \\
\text { (approximate) }\end{array}$ & $\begin{array}{c}\text { Age at } \\
\text { death }\end{array}$ & $\begin{array}{c}\text { Cause of } \\
\text { death }\end{array}$ \\
\hline Sven & farmhand & $\begin{array}{c}\text { unskilled } \\
\text { worker }\end{array}$ & $\begin{array}{c}\text { f. unskilled } \\
\text { worker/ pauper }\end{array}$ & 29 & 14 & 47 & Wasting \\
\hline Johannes & farmhand & $\begin{array}{l}\text { f. prison } \\
\text { guard }\end{array}$ & f. guard & 23 & 22 & 45 & Wasting \\
\hline Peter & farmhand & $\begin{array}{l}\text { unskilled } \\
\text { worker }\end{array}$ & $\begin{array}{c}\text { f. unskilled } \\
\text { worker/ pauper }\end{array}$ & 27 & 44 & 70 & $\begin{array}{c}\text { General } \\
\text { weakness }\end{array}$ \\
\hline Lars & $\begin{array}{l}\text { town clerk } \mathrm{f} . \\
\text { manservant }\end{array}$ & caretaker & $\begin{array}{l}\text { f. town clerk/ } \\
\text { pauper }\end{array}$ & 37 & 19 & 49 & Wasting \\
\hline Johan Z. & tailor & f. tailor & f. tailor/ pauper & 21 & 25 & 49 & $\begin{array}{l}\text { drunken- } \\
\text { ness }\end{array}$ \\
\hline $\begin{array}{l}\text { Johan } \\
\text { Carl }\end{array}$ & drummer & drummer & f. drummer & $\begin{array}{c}18(31 \\
\left.\text { and } 52^{*}\right)\end{array}$ & 17 & 56 & Dropsy \\
\hline Johan $\mathbf{H}$ & farmhand & extra guard & f. guard & $40\left(45^{* *}\right)$ & 19 & 50 & Wasting \\
\hline Peter P. & farmhand & farmhand & $\begin{array}{l}\text { (f.) worker/ } \\
\text { pauper }\end{array}$ & 29 & 52 & 83 & $\begin{array}{l}\text { old age- } \\
\text { wasting }\end{array}$ \\
\hline Johan E. & manservant & manservant & $\begin{array}{l}\text { f. manservant/ } \\
\text { pauper }\end{array}$ & 30 & 46 & 86 & $\begin{array}{l}\text { old age- } \\
\text { wasting }\end{array}$ \\
\hline Mean: & & & & 28.22 & 28.66 & 59.44 & \\
\hline Median: & & & & 29 & 22 & 50 & \\
\hline
\end{tabular}

Sources: DDB/ LHD, Church registers; Genline, Church registers; SVAR, Church registers on Micro cards. ${ }^{*}$ Second and third marriage respectively. ${ }^{* *}$ Second marriage.

Comment: second and third marriages are excluded when calculating mean and median age of marriage respectively.

though they spent approximately 22 years in Linköping which is quite a long time before they died at a median death age of 50 . A closer look reveals further information about what happened to these men after their arrival in town.

Johannes arrived in Linköping as a recently married 23-year old, "tailor hand" ("skräddaredräng"). The bride was from Linköping so they settled there. The first years in town he might have continued working as a tailor hand, although he is just called dräng. Soon after his arrival he changed his occupation, now being a guard at the castle (where prisoners were kept), later on he was a gardener (probably in the park of the castle) and finally a guard during transportations of prisoners ("Fangtransport Gevaldiger"). He quit working when he was 37 years old. By then he had five children and a wife to provide for. The year before, the family had lost their baby daughter of seven months, from slag and Johannes mother- in- law, who had lived with the family for a long time and who died from a chest disease ("Bröstsj."). She had received poor relief. Elderly women supported both by poor relief and by their children's household are not particularly rare, according to another study. The elderly women might have contributed with keeping the home clean and taking care of the children. If so, this

108 Number of years spent in town and age of death is calculated by calendar year, i.e. without considering months of birth or any other dates. This procedure means that some of the men have not yet reached the age stated in the table. 
was an arrangement surviving from the traditional agrarian society. ${ }^{109}$ Johannes died from a "Wasting" ("Tärande") disease when he was 45 years old. ${ }^{110}$ He had probably, as Sven, been unable to work due to his illness the previous years before death but there are no indications that he had been given any poor relief. He left his wife with two daughters still in the household.

Peter moved to Linköping when he was 26 years old. He married a maid who had moved to Linköping before Peter. There he started to work as an unskilled worker (arbetskarl) but when Peter was in his thirties he got "sickly" ${ }^{111}$ and never recovered. In his forties he was out of means and could not pay taxes. ${ }^{112}$ By then, they got five children to feed. Peter and his wife spent their old age in different locations. Peter's wife moved away and took the children with her. Peter lived his last six years at the poor house where he died from "general weakness", 70 years old. ${ }^{113}$

Lars Petter moved to Linköping when he was 32 years old. He was registered as a "former manservant" ("betjent") and a town clerk ("statsfogde"/stadsfogde). ${ }^{114}$ This was not work just anyone could be trusted with. However, he had an illegitimate affair with a maid in town who previously had given birth to another illegitimate child. They had a daughter who lived with her mother until they began their life together three years later. He took her as his wife in a religious procedure called kyrktagning. ${ }^{115}$ It took seven years until the real wedding ceremony took place and he lawfully married the mother of his child. By then he had got himself a job as a caretaker ("vaktmästare"). His career as a town clerk was most likely over and seems to coincide with his moral escapade. ${ }^{116}$ Lars became a pauper probably because of the wasting disease which he eventually died from, 49 years old. Besides Lars illness, there was "consumption" 117 in the household. His mother-in-law died from it a couple of months before Lars died. She had been living with Lars' family from the start and she was out of means the last years of her life.

109 Birgitta Plymoth, Fostrande försörjning: Fattigvård, filantropi och genus i fabriksstaden Norrköping 1872-1914 (Almqvist \& Wiksell International, Stockholm, 2002), p. 177ff, 181.

110 DDB/LHD, Dödboken för Linköpings Domkyrkoförsamling, vol. 607, p. 791.

111 DDB/LHD, Husförhörslängden för Linköpings Domkyrkoförsamling, vol. 29, p. 404.

112 DDB/LHD, Husförhörslängden för Linköpings Domkyrkoförsamling, vol. 41, p. 584.

113 DDB/LHD, Husförhörslängden för Linköpings Domkyrkoförsamling, vol. 60, p. 103 and Dödboken för Linköpings Domkyrkoförsamling, vol. 612, p. 836.

114 DDB/LHD, Inflyttningslängden för Linköpings Domkyrkoförsamling, vol. 203, p. 0120.

115 It was a kind of betrothal within folkloristic traditions, see further, Ann-Sofie Ohlander, "Att vänta barn på bröllopsdagen: Föräktenskapliga förbindelser och giftermålsmönster i 1800-talets Sverige", in Kärlek, död och frihet: Historiska uppsatser om människovärde och livsvillkor i Sverige (Norstedts, Stockholm, 1986), p. 68ff; D. Gaunt (1983), p. 69.

116 To be noted though, when he was 37 years old, he announced in the local newspaper, in his search for people who might have a claim on or be indebted to a certain deceased widow of a town servant ("Stadsbetjent"). He signed the announcement by using the title, "former town clerk". It is not clear whether he did this in his professional role. See Östgöta Correspondenten, 18390817.

117 Genline, Dödboken för Linköpings Domkyrkoförsamling, vol. C: 9, p. 297. 
Johan $\mathrm{Z}$ moved to Linköping as a tailor master with a pregnant wife and a son, in $1825 .{ }^{118}$ The following year he was at the height of his career, being called "Mr." ("Herr"). ${ }^{119}$ His family was extended with four sons and a daughter. In 1835 he was accused of theft which was punishable by the church. ${ }^{120}$ After that incidence, Johan's professional life was over and he was from now on called "former tailor", ${ }^{121}$ at the age of 35 . He had trouble supporting his large family, which eventually was separated. The daughter was sent away as a foster child. ${ }^{122}$ One son was looked upon as "vicious" and received corporal punishment for "shoplifting". ${ }^{123}$ Johan's life was ended at the poorhouse where he lived for four years and finally died from "drunkenness". ${ }^{124}$ The year before he died he had been accused of another theft. Two of his sons, the daughter and his wife also lived at the poorhouse for a while.

Johan Carl moved to Linköping when he was fifteen years old but returned the year after to his mother. ${ }^{125}$ He was probably already assigned to be a military musician at the regiment in Linköping, since he was called a "drummer". ${ }^{126} \mathrm{He}$ moved back to Linköping when he was eighteen and married a woman who was 43 years old and who had three illegitimate children. ${ }^{127}$ They moved back to his mother where Johan's wife contributed to the household economy by selling liquor without permission. ${ }^{128}$ One of her children, now a stepdaughter of Johan Carl, got relief from a friendly society. ${ }^{129}$ She moved away at the age of twelve to Linköping, probably as a foster child. ${ }^{130}$ Ten years later Johan became a widower. ${ }^{131}$ He remarried the year after and moved to Linköping again with his new wife. When Johan retired from his work as a military musician he was 47 and his family moved back to his mother. Johan received a pen-

118 DDB/LHD, Inflyttningslängden för Linköpings Domkyrkoförsamling, vol. 202, p. 0108.

119 DDB/LHD, Husförhörslängderna för Linköpings Domkyrkoförsamling 1831-1835. Herr means mister or master but was used among the four estates in Sweden until 1867, see S. Carlsson (1968), p. 281.

120 DDB/LHD, Husförhörslängden för Linköpings Domkyrkoförsamling, vol. 34, p. 134.

121 The first notification can be seen in DDB/LHD, Husförhörslängden för Linköpings Domkyrkoförsamling, vol. 36, p. 134.

122 DDB/LHD, Husförhörslängden för Linköpings Domkyrkoförsamling, vol. 41, p.418 and vol. 47, p. 252. In the latter churchbook she was called "fattigbarn", which meant that she was a poor child.

123 DDB/LHD, Husförhörslängden för Linköpings Domkyrkoförsamling, vol. 41, p. 418.

124 DDB/LHD, Husförhörslängden för Linköpings Domkyrkoförsamling, vol. 43, p. 234; Dödboken för Linköpings Domkyrkoförsamling, vol. 609, p. 282.

$125 \mathrm{He}$ has not been found in the church registers of Linköping. It is not certain that this was his first move to Linköping since he had moved to an unknown destination before.

126 DDB/LHD, Husförhörslängden för Sankt Lars församling, vol. 6, p. 130.

127 Genline, Husförhörslängden för Sankt Lars församling, vol. A1:6, p. 130. According to the priest she had five illegitimate children. However, only three are identified in the church register and are also mentioned later on by the priest.

128 DDB/LHD, Husförhörslängden för Sankt Lars, vol. 8, p. 150.

129 DDB/LHD, Husförhörslängden för Sankt Lars, vol. 8, p. 150. The friendly society was called Serafimergillet.

130 DDB/LHD, Husförhörslängden för Sankt Lars, vol. 8, p. 150.

131 DDB/LHD, Dödboken för Sankt Lars församling, vol. 606, p. 285. 
sion from the army. ${ }^{132}$ He lost his wife, and was once again a widower. He also lost his five years old daughter, from a "Chest disease" ${ }^{133}$ and now he was on his own because their first child had died some years before from "Sudden death" ("Slag") ${ }^{134}$, five months old. He remarried three years later and moved to Linköping once again where his wife already lived with her illegitimate child from before. They lived for the first part of their marriage with Johan's father-in-law and his wife. Three years later Johan was sent to prison for theft. He was punished to work there for one year and shortly before he had made amends for his crime and was to be let out, he died from "Dropsy" ("Vattusot"), ${ }^{135}$ while still in prison, 56 years old.

When Johan Henric came to Linköping he was a 31 years old farmhand. ${ }^{136} \mathrm{He}$ held this title until he changed occupation and became "Extra Guard" ("Extra Vaktkarl'). ${ }^{137} \mathrm{He}$ married a maid in town soon after that, 39 years old. ${ }^{138}$ In the middle of his forties he bought a house in town. This could be an indication of success in some sense and was maybe related to his occupation since this has been found in two other cases for persons with the same occupation. ${ }^{139}$ However, within a couple of months he became a widower, 44 years old, and was also hospitalized for "Rheumatism" in his knee. The hospital record shows that he was infected with "syphilis which however not at present is contagious". He was also found to have a flat nose due to a punch on it. Furthermore, it was noticed in the record that "he is keen on hard liquors". ${ }^{140}$ His wife had recently died in connection with the delivery of their second son. ${ }^{141}$ Half a year after he left the hospital, he remarried. ${ }^{142}$ He had a son with his new wife but the infant died from "Sudden death" ("Slag"), eleven days old. ${ }^{143}$ They had a daughter who died $31 / 2$ years old, from "Sudden dealth" ("Slag"), as well. ${ }^{144}$ By then Johan Henric had been dead for about two months. He died from

132 DDB/LHD, Husförhörslängden för Sankt Lars församling, vol. 18, p. 163 and vol. 20, p. 163.

133 DDB/LHD, Dödboken för Sankt Lars församling, vol. 607, p. 201.

134 DDB/LHD, Dödboken för Linköpings Domkyrkoförsamling, vol. 607, p. 791.

135 DDB/LHD, Dödboken för Linköpings Domkyrkoförsamling, vol. 610, p. 412.

136 DDB/LHD, Inflyttningslängden för Linköpings Domkyrkoförsamling, vol. 203, p. 0132.

137 DDB/LHD, Husförhörslängden för Linköpings Domkyrkoförsamling, vol. 37, p. 528. In the estate inventory made after his death, he is called "the former guard of the castle" ("förre Slottsknekten").

138 DDB/LHD, Vigselboken för Linköpings Domkyrkoförsamling, vol. 5070, p. 538.

139 DDB/LHD, Husförhörhörslängden för Linköpings Domkyrkoförsamling, vol. 41, p. 206. Another "Extra Vaktkarl" owned the house where Johan Henric lived for a while, see DDB/LHD, husförhörslängden för Linköpings Domkyrkoförsamling, vol. 37, p. 528. Another man in the migrant primary cohort (but not included in this migrant profile category), was a guard and owned a house as well.

140 Patient record, Lasarettet i Vadstena, Patient N:o 129, 18461024.

141 DDB/LHD, Dödboken för Linköpings Domkyrkoförsamling, vol. 609, p. 248.

142 DDB/LHD, Vigselboken för Linköpings Domkyrkförsamling, vol. 5090, p. 185.

143 DDB/LHD, Dödboken för Linköpngs Domkyrkoförsamling, vol. 609, p. 264.

144 DDB/LHD, Dödboken för Linköpings Domkyrkoförsamling, vol. 609, p. 314. 
"Wasting disease", when he was 50 years old in 1852. ${ }^{145}$ By the time of his death, he no longer owned a house, was out of work and "crippled". ${ }^{146}$ Five days after his death, another son was born. ${ }^{147} \mathrm{He}$ and his mother and his siblings were left with an indebted household. Among other things there was a debt for renting a dwelling. ${ }^{148}$

Peter P was already married when he moved to Linköping, 31 years old. He got a job, still called farmhand. The couple had two daughters. In addition, his wife had an illegitimate son from before. Their second daughter died however from dysentery ("Rödsot"), almost three years old. Next year, a son was born who died from "chest disease" when he was an infant. When Peter was about 40 years old, the family's problem became more apparent. His wife was a "pauper". Peter was said by the priest to be "drinking". This judgement followed him later on in the church registers. $\mathrm{He}$ and his wife had another daughter who died from "Sudden death" ("Slag"), one week old. When Peter was about 50 years old, he was out of work ("Försvarslös"). His wife was now "crippled". In 1867, when he was 65 , he moved to the poor house and never returned home. 18 years later he died there from "old age wasting".

At the same poorhouse Johan E. spent his last 20 years of life before he died from old age wasting, 86 years old. He had come to Linköping as a 26 years old manservant but he moved out again shortly after. He came back along with his family when he was 40 years old. He worked as a manservant in Linköping until he was about 45 years old and for some reason quit working. By then he had two daughters, besides his wife, to support at home. His wife was convicted of first time theft 1859. She died the same year, leaving Johan E. alone. He never remarried and eight years later he moved to the poor house.

How can these migrant men's destinies be understood? When studying their settlement in town certain patterns can be noticed. Like Sven, they managed to get through the first eye of the needle, which was to get a job, i.e. "Legal defence" ("Laga forsvar"), as demanded to be permitted to stay in town. ${ }^{149}$ To be noticed though, is that not all of them "settled" their first time in town. In a migratory turbulent town like Linköping, at least five years of stay has been considered a criterion of being "settled" ${ }^{150}$. Johan Carl, for example, who moved, even while married, back and forth several times between his mother in a nearby parish and Linköping is a reminder, as also

145 DDB/LHD, Dödboken för Linköpings Domkyrkoförsamling, vol. 609, p. 311.

146 DDB/LHD, Husförhörslängden för Linköpings Domkyrkoförsamling, vol. 45, p. 486.

147 DDB/LHD, Födelseboken för Linköpings Domkyrkoförsamling, vol. 310, p. 20.

148 Landsarkivet i Vadstena, Bouppteckning, vol. B 66, p. $53 \mathrm{ff}$.

149 A. Montgomery (1951), pp. 55-65. Legal defense meant that a person was forced by law to be employed if there were no private means to support oneself. Otherwise, the person risked being sent to an institution for forced labour. Between 1919 och 1933 the Act of Legal defense was reformed, meaning that only beggars and criminals without Legal defense were threaten with institutionalization with forced labour.

150 Anders Brändström, Jan Sundin, Lars-Göran Tedebrand, "Two Cities: Urban Migration and Settlement in Nineteenth-Century Sweden", The History of the Family, vol. 5 No. 4 (2000), pp. 415-429, quotation p. 416. 
Sven is, that the same individuals could appear in the migration statistics for a town more than once. Usually though, it "meant the end of a migration career" to get married. ${ }^{151}$ This was true for the other migrants' settlement during which all got married, if they were not already married when they arrived in town. As table 1 shows, their mean age of marriage was 28 .

Notably, these migrants' hardest time in town appears to be when these migrant men had a family to support. Due to different circumstances they failed in doing so. Life events which affected the whole family came to the surface. Their miserable situation is indicated by the often repeated infant and childhood mortality among these families, which often coincided with what appears to be a time of culminated crisis. ${ }^{152}$ Several of these men were hit by chronic and degenerative illnesses, where in some cases binge drinking can be suspected to be involved. A prolonged period of illness must have caused inability to work and provide for their families' and their own well-being. Failure to keep a job, even if not being ill, seems to have been the case for some of them too, as well as incidents of criminal or immoral behaviour, according to the standard of the time. Some of these men had even begun a professional career (although modest), which was interrupted in town, like in Lars' or Johan Z.'s case. In those examples nothing but a moral sidestep can be detected when trying to understand what happened in these men's lives. Thus, the men in this study do not seem to have faced their most risky and difficult time as single, young men who recently had arrived in town, compared to what is known from previous studies. ${ }^{153}$ There can of course be a hidden chronology of despair in their lives as well, hence accumulating effects of hard times. The procedure of selection not to forget, guarantees that this group of men was alive in their forties as well. In any case, the socioeconomic problems that several of these men had already experienced earlier in life seems to recur or be aggravated in town in a phase of life when they were settled with wife and children.

151 Ibid., p. 427.

152 M. Bengtsson (1996), p. 173ff., 195. Bengtsson demonstrates that during the middle of the nineteenth century the family had a decisive impact upon infant mortality. The risk of dying as an infant was three times higher if a close sibling had died previously compared to those infants with a close sibling who had survived the first year of life. This was a fact regardless of social belonging. Moreover, the frequent diagnosis, "Slag", had a social dimension and was most prevalent among the lowest layers of the social hierarchy.

153 W. H. Sewell, Jr. (1985), p. 221-232; L. P. Moch, Paths to the City: Regional Migration in Nineteenth-Century France (Sage Publications, Beverly Hills, 1983), pp. 125-132; L. P. Moch, Moving Europeans: Migration in Western Europe since 1650 (Indiana University Press, Bloomington \& Indianapolis, 1992), p. 144f.; S. Willner (1999), p. 236-247; J. Sundin, "Äktenskap, ensamskap och hälsa förr och nu: Tankar kring ett forskningsfält", in Individ och struktur $i$ historisk belysning. Festskrift till Sune Akerman, eds., Tom Ericsson \& Agneta Guillemot. Forskningsrapport nr. 10. Historiska institutionen, Umeå universitet (Umeå, 1997), pp. 219-245. 
This is interesting, since marriage is looked upon as "a key step toward becoming integrated in the urban environment". ${ }^{154}$ Social integration is a concept referring to social relations and social commitments in society and the meaning of social belonging to individuals. ${ }^{155}$ It is often viewed as an important health determinant. ${ }^{156}$ The phenomenon of higher mortality among unmarried men than among married in contemporary societies can for instance be interpreted, inspired by Emile Durkheim, as related to lack of social integration and social control which husbandhood and parenthood can provide, probably with important consequences for health conduct. ${ }^{157}$ The husband and fatherhood role can however be affected if other "core social roles", like the work role, are unsatisfactorily fulfilled. This could lead to stress and a yearning to eliminate that stress, sometimes by applying a destructive health behaviour, like smoking and drinking. ${ }^{158}$ Here, gender is an issue, because the socially accepted behaviour of men and women differs, and these differences change over time. Men and women in nineteenth century Sweden did not have the same "rights" behaviourwise. Some were "positive" and some were "negative", viewed from a health perspective. ${ }^{159}$ In this context of understanding, it could be fruitful to turn the interest to the spouses of migrant men. Who were they and how do their life courses appear when compared to their husbands'?

\section{Spouses of 'Migrant Men in Misery'}

Among those five migrants who got married in Linköping, only Johannes and Johan Carl married women born in Linköping. Still, Johan Carl's first bride was a woman born elsewhere than Linköping. Migrants' inclination to marry other migrants has been noticed in earlier demographic research of Linköping, as well as Sundsvall, and is interpreted as part of a marriage behaviour pattern aiming to maintain cultural steadi-

154 A. Brändström, J. Sundin, L-G. Tedebrand, ”Marriage and Urban Adaption: Sundsvall and Linköping in XIXth Century Sweden", Annales de Démographie Historique, 2 (1999), pp. 97114, quotation, p. 103.

155 Social integration is a concept originally used by Emile Durkheim in his classic study of suicide (Le Suicide, orig. 1897), Självmordet (Argos Förlags AB, Uppsala, 1968), see p. 155. "The more lively interaction and the more contacts between members of the group, the stronger is the group integrated." Quotation are translated by the author of this paper from the Swedish translation.

156 When migrants' possibilities to integrate in a new place are evaluated, their health status has, on the other side, also been used as an indicator of their potential success. See S. Edvinsson and H. Nilsson (1999), p. 63.

157 Debra Umberson, "Family Status and Health Behaviours: Social Control as a Dimension of Social Integration", Journal of Health and Social Behavior, vol. 28, No.3 (1987), pp. 306-319.

158 Johannes Siegrist, "Place, social exchange and health: proposed sociological framework", Social Science and Medicine, vol. 51 (2000), pp. 1283-1293.

159 S. R. Johansson (1991), pp. 135-177. 
ness in new situations and surroundings. ${ }^{160}$ This has to be considered along with the fact that migrants actually were in the majority in Linköping. ${ }^{161}$

However, the endogamy was also "social" ${ }^{162}$, and indicates a socially stratified marriage market, where a person born in town was highly valued. ${ }^{163}$ The 'migrant men in misery' married women with a similar social background. Johan Carl got married three times and Johan Henric got married twice while the others only got married once. Out of twelve wives, childhood information on 10 wives has so far been possible to gather. As has been shown above, Sven and Stina had a common history as servants in the same household at the time of their engagement. Stina was a daughter of a crofter, who eventually became owner of a small piece of land. Johan Carl's first wife, Cristina Malmberg "164, had been living in the same cabin ("backstuga") as Johan Carl before him and hence shared his geographical and social background. She was however 25 years older than him and had three illegitimate children. This social circumstance was familiar to Johan Carl who himself was an illegitimate child. His second wife, Sara Sofia Tollsten ${ }^{165}$, was a half-sister to Johannes Tollsten (a member of the cohort) and although she grew up in another parish than him and did not lose her mother as a child, she could be said to share a similar social background as him. Johan Carl's third wife, Dorotea Wilhemina Sandberg ${ }^{166}$, was born in Linköping but, like Johan Carl, she was a child born without an official father. Her mother was a maid almost in the same age as Johan Carl. Dorothea lost her mother when she was 16, but by then she had a stepfather. Johannes wife, Anna Stina Brunelius, ${ }^{167}$ was born in Linköping. Her father was a military carpenter ("Timmerman") but he died when Anna Stina was a young teenager. Her mother was "sickly" and received poor relief. ${ }^{168}$ After a prolonged time of relationship, Lars married a maid who was living in the same neighbourhood as Lars when he moved to Linköping. Brita Christina Wiman's

160 A. Brändström, J. Sundin, L-G. Tedebrand (1999), p. 109ff; L. Vikström (2003), p. 192. However, Vikström did not find a pattern where the spouses were born in the same parish or arrived to Sundsvall from the same parish.

161 See also Michel Oris, ”The age at marriage of migrants during the industrial revolution in the region of Liège", The History of the Family, vol. 5, No. 4 (2000), pp. 391-413.

162 A. Brändström, J. Sundin, L-G. Tedebrand (1999), p. 110.

163 See also Margareta Matovic, "Migration, Family Formation, and Choice of Marriage Partners in Stockholm, 1860-1890", in Urbanization in History: A Process of Dynamic Interactions, eds., AD van der Woude, Akira Hayami \& Jan de Vries (Clarendon Press, Oxford, 1990), p. 230, 239.

164 Christina Malmberg is told in the churchbook of DDB/LHD, Linköpings Domkyrkoförsamling, vol. 22, p. 514, to have been born 1777 in Jönköping, but this has not been possible to confirm.

165 Sara Sofia Tollsten was born in Kärna 18160515, according to Genline, Kärna födelsebok 1816, vol. C:3 1808-1856, p. 41.

166 Dorothea Wilhemina Sandberg was born in Linköping 1827-04-14, according to DDB/LHD, Födelseboken för Linköpings Domkyrkoförsamling, vol. 307. p. 24.

167 Anna Stina Brunelius was born 1770314 in Linköping, according to DDB/LHD, Födelseboken för Linköpings Domkyrkoförsamling, vol. 303, p. 414.

168 DDB/LDDB, Husförhörslängden för Linköpings Domkyrkoförsamling, vol. 15, p. 164. 
${ }^{169}$ father was a manservant and they moved to Linköping when Brita Stina was four years old. When she was seven years old, she lost her father. Anna Lisa Follin, ${ }^{170}$ the wife of Petter E., was fatherless too as a child. Her father was an unskilled worker at the town customs office. He died when Anna Lisa was seven years old. Her mother remarried six years later with another unskilled worker. Johan Henric's second wife, Anna Greta Sandberg ${ }^{171}$, was a daughter to a farmer who did not own the land himself ("brukare"). He added to his income by making buttons. Her mother was "sickly" and was recommended by the priest to be dismissed from paying taxes. ${ }^{172}$ When Anna Greta was 14 years old her father died in a poor state. Johan Zettergren's wife, Lisa Qvarnström, ${ }^{173}$, was the daughter of a miller. He died from "chest disease" when Lisa was 13 years old. ${ }^{174}$ Lisa moved to stay within another household some time after. She moved to the town Örebro when she was 20 , where she soon met her husband to be. $^{175}$

Unlike the above mentioned spouses, there are no indications of social distress in the childhood of Johan Henric's wife, Johanna Carlsdotter ${ }^{176}$, who was the daughter of a quite wealthy farmer (rusthållare ${ }^{177}$ ) and Peter P's wife, Carin Jonsdotter, ${ }^{178}$ who was born in a farmer family. However, the information on these women's childhood is limited. There is no information found on the childhood of Johan E.'s wife, Helena Catharina Persdotter, ${ }^{179}$ as was the case with Christina Malmberg, the wife of Johan Carl.

Knowing that these migrant men in most cases married migrant women (defined as not born in Linköping) and women from the same social layers, it is of interest to see how these women's lives went on in town. Age of marriage with cohort migrant man,

169 Brita Stina Wiman was born i Kärna, 18070222, according to DDB/LHD, Födelseboken för Kärna församling, vol. 302, p. 412.

170 Anna Lisa Follin was born in Skänninge, 1804-11-02, according to Genline, Födelseboken för Skänninge stad 1804, vol. C:3 1795-1841, p. 97.

171 Anna Greta Sandberg was born in Slaka 1822-01-09, according to DDB/LHD, Födelseboken vol. 305, p. 53.

172 DDB/LHD, Husförhörslängden för Slaka, vol. 6, p. 338.

173 Lisa Qvarnström was born in 17991124 in Bergslagen, Filipstad, according to Genline, Födelseboken för Filipstad, Bergslagen, vol. C:7, 1779-1809, p. 349.

174 Genline, Dödboken år 1812 för Kvistbro, Örebro, vol. C: 6, 1801-1815.

175 Genline, Husförhörslängden för Örebro, Askersunds Landsförsamling, vol. A1: 4B, 18161820, p. 144; Inflyttningslängden för Örebro, 1819, vol. A1: 16B, 1816-1820 GID 2316.102.66700.

176 Johanna Carlsdotter was born in Flistad, 18131007, according to Genline, Födelseboken för Flistad 1813, vol. C: 2 1794-1837. Her childhood has not been possible to follow after she was about six years old.

177 This means that the farm had capacity to contribute to the army with a horse and armour.

178 Carin Jonsdotter was born in Östra Ryd, 18010814, according Genline, födelseboken för Östra Ryd, 1801. Her childhood has only been possible to follow until she was about eight years old.

179 Helena Catharina Persdotter was born in Vetlanda 18070623, according to Genline, födelseboken för Vetlanda 1807. She has not been found in the church register, called Husförhörslängderna. 
Table 2. The spouses of migrant men in misery: Age of marriage, years of marriage, years spent in Linköping, widow of migrant man/age, out migration from Linköping as a widow to a migrant man /age, age of death and cause of death. ${ }^{180}$

\begin{tabular}{lccccccc}
\hline Spouse ID & $\begin{array}{c}\text { Age of } \\
\text { marriage }\end{array}$ & $\begin{array}{c}\text { Years of } \\
\text { marriage }\end{array}$ & $\begin{array}{c}\text { Years } \\
\text { spent in } \\
\text { Linköping } \\
\text { (approx.) }\end{array}$ & $\begin{array}{c}\text { Age of } \\
\text { being } \\
\text { widow }\end{array}$ & $\begin{array}{c}\text { Age of } \\
\text { migration } \\
\text { from } \\
\text { Linköping } \\
\text { as a widow }\end{array}$ & $\begin{array}{c}\text { Age of } \\
\text { death }\end{array}$ & $\begin{array}{c}\text { Cause of } \\
\text { death }\end{array}$ \\
\hline Stina & 23 & 18 & 30 & 41 & 58 & 59 & Unknown \\
Brita & 32 & 12 & 42 & 44 & 45 & unknown & Unknown \\
Christina & 24 & 22 & 50 & 46 & no & 52 & Consumption \\
Anna Stina & 23 & 43 & 51 & 66 & no & 69 & Consumption \\
Anna Lisa & 29 & 4 & 6 & no & no & 33 & Childbirth \\
Johanna & 25 & 5 & 12 & 30 & 35 & unknown & Unknown \\
Anna Greta & 30 & 44 & 42 & no & no & 74 & Consumption \\
Carin & 25 & 27 & 17 & no & no & $52^{*}$ & Unknown \\
Helena C & 23 & 28 & 31 & 51 & no & 57 & Wasting \\
Lisa & 43 & 12 & 8 & no & no & 55 & Sudden death \\
Christina & 17 & 18 & 12 & no & no & 35 & Plag") \\
Sara & 27 & 4 & 54 & 31 & noxes & 62 & Cancer in \\
Wilhelmina & 26.75 & 19.75 & 29.58 & 44.14 & & 54.8 & liver \\
\hline Mean: & 25 & 18 & 30.5 & 44 & & 56 & \\
\hline Median: & 25 & & & & & & \\
\hline
\end{tabular}

*This information has not been possible to confirm in the mortality register (Dödboken).

${ }^{* *}$ She moved out as a remarried widow at the age 35 .

Sources: DDB/LHD, Church registers; Genline, Church registers; SVAR, Church registers on Micro cards.

years of marriage with cohort migrant man, years spent in Linköping, widow of cohort migrant man/age, out migration as a widow, age of death and cause of death, are summarized in table 2.

The women spent in average 19 years of their lives along with their men, which is quite a long period of time. In fact it was probably even longer since in seven out of twelve marriages there was a pre-marital conception. ${ }^{181}$ This was a common pattern in several districts in Sweden among the poorer social layers and is interpreted as an accepted behaviour when the couple already had decided to get married. ${ }^{182}$ These women spent on average almost the same number of years as the migrant men in town, but the variation was large between the women. The women died predomi-

180 All numbers are calculated by calendar year, i.e. without considering months of birth or any other dates. This means that some of the women have not yet reached the age/time stated in the table. The women's age of marriage is not restricted to first marriages, as is the case with the men's mean and median age of marriage respectively in table 1.

181 In the case of Johan Edoff and his wife, their first born daughter was called "illegitimate" by the priest. See Genline, Födelseboken för Västerlösa 1832, vol. C: 4, p. 155.

182 A-S. Ohlander (1986), p. 81. 
nantly from chronic diseases, except the diagnosis childbirth, poxes and sudden death (which might however be stroke). Their age of death varied too, like the migrant men's in the cohort, which makes it hard to see any gendered patterns. ${ }^{183}$ All (among whom the age of death is known) but three men and three women died before their 60th birthday. The few men and women who managed to reach old age, apparently did so despite their miserable lives. However, age of death is not the only factor that needs to be taken into consideration when comparing these spouses' lives.

In fact seven out of twelve wives outlived their husbands. Viewed from the men's perspective, all men but Petter P. and Johan E. (who both became very old) left a widow when they died. To count the widows' survival years requires that the spouses' age at marriage is regarded as well, which is shown below in table 3 .

In this selected group, shown in table 3, the men got married within the wide span of age 21 and age 52 and the women got married between age 23 and age 32 . The mean age of marriage among all nine men was 28 and among all 12 women nearly 27 , as is shown in tables 1 and 2, respectively. Previous research regarding marriages in Linköping 1850-1855, shows that men had a mean age of 29 and women 27.6. ${ }^{184}$

When it comes to migrants, it has been shown that migrant men in 19th century preindustrial Sundsvall had a mean marriage age of 28.6 and migrant women 28.1, respectively. The age difference between the spouses was found to be slighter than was the case among the spouses in table 3, where the age difference was quite distinct. Vikström's cohort was however selected on different grounds. ${ }^{185}$ When the age differences between the spouses in table 3 are taken into account, only Stina's number of survival years seems outstanding. Does this imply that these couples shared the heavy burden of life in town in a similar way?

When each couple is matched together and viewed qualitatively, and the focus is put on the apprehended 'life crisis', some of these women, as mentioned before, were certainly not excluded from difficulties. As in Stina's case, Anna Greta was infected with venereal disease and was hospitalized for about a month. ${ }^{186}$ Since her husband to be, Johan Henric, also was infected at the time, there seems to be a connection.

183 The 10 women of whom the age of death is known, had a median age of death that was higher than the 9 men's but the women's mean age of death is lower than the mean age of death of the men in the cohort. The latter is contradictory to L. Vikström's (2003), p. 150-151, findings concerning $19^{\text {th }}$ century industrialized Sundsvall, where migrant men had a tendency to die at a younger age than migrant women, which is also in line with the theory of "vulnerable men". However, Vikström has not made any comparison between spouses regarding longevity. Nevertheless, the numbers in the present study are far too small to draw any safe conclusions. Furthermore, the comparison between the spouses is complicated by the fact that the spouses started their married life together at different ages.

184 A. Brändström, J. Sundin, L-G. Tedebrand (1999), p. 108, table. 9.

185 L. Vikström (2003), p. 189. The compared cohorts in Vikström's study are much larger, containing 97 men and 79 women.

186 Hospital record, Länslasarettet i Vadstena, Vadstena Kurhus, Överläkarens arkiv, patient N:o 125, år 1846. The diagnosis was called ”Dröppel”. 
Table 3. Couples where the wife outlived the husband. The spouses age of marriage and number of survival years among the widows. ${ }^{187}$

\begin{tabular}{lcccc}
\hline \multicolumn{2}{c}{ Groom } & \multicolumn{2}{c}{ Bride } & $\begin{array}{c}\text { No of survival years of widow } \\
\text { after husband's death }\end{array}$ \\
\hline Name & Age & Name & Age & \\
Sven & & & & \\
Johannes & 29 & Stina & 23 & 6 \\
Peter E & 23 & Anna Stina & 24 & 3 \\
Lars Petter & 27 & Anna Lisa & 23 & Min. 1 (out migration) \\
Johan Z & 37 & Brita Christina & 32 & 6 \\
Johan Carl & 21 & Lisa & 23 & 31 \\
Johan Henric & 52 & Wilhelmina & 27 & Min. 5 (out migration) \\
\hline Mean & 45 & Anna Greta & 25 & \\
\hline Median & 33.42 & & 25.28 & \\
\hline Sources: DD & 29 & & 24 & \\
\hline
\end{tabular}

Sources: DDB/LHD, Church registers; Genline, Church registers; SVAR, Church registers on Micro cards.

Anna Lisa and Peter E. spent their last years as married in separate locations. Anna Lisa lived at an institution, probably in order to work for her support. She became a pauper the last year of life. Lisa had to move to the poor house when her husband Johan ended up there. However, she spent her last years elsewhere than the poor house. Among the other spouses who died before their husbands, Carin was "crippled" when she was in her middle age ${ }^{188}$ and Helena Christina was accused of first time theft and breaking of the Sabbath the same year she died. A criminal act was also committed by Johan Carl's first wife Christina who was said to be selling aquavit, without a license. ${ }^{189}$ However, no other striking indications of the women's individual role in the problems (like sickness or criminal behaviour) they faced as a family, have been found among these spouses of migrant men in misery.

When comparing the known life circumstances in town for the men and their spouses, it is not easy to come to a straightforward conclusion. Rather, the findings are somewhat ambiguous. Pure mathematics has not revealed any remarkable differences between the couples. There seem to be no apparent advantages for the women as far as their demographic features can tell. The small numbers contained quite scattered figures though and require an interpretation with great caution. For instance, the society in change that they lived in can be expected to give chance a greater role for the outcomes of these individuals' lives, than what would probably be the case in a more sta-

187 All numbers are calculated by calendar year, i.e. without considering months of births or any other dates. This means that some of the men and women have not yet reached the age/time stated in the table. The brides' age of marriage is not restricted to the first marriages, as is the case with the grooms' mean and median age of marriage, respectively.

188 DDB/LHD, Husförhörslängden för Linköpings Domkyrkoförsamling, vol. 47, p. 606.

189 According to Iréne Artæus these women should not be looked upon as criminal in the real sense, since they seldom committed any other crimes. See I. Artæus (1992), p. 157. 
ble society. ${ }^{190}$ When the whole life history analysis is reflected upon, there is nevertheless a lingering impression of imbalance between the life courses of the men and their spouses, regarding the different roles involved in what has been considered as the nature of their problems in town. Although the women most likely suffered from their dreadful family situation, their 'stand back' role might have made them able to cope with their lives somewhat better. Indeed, this hypothesis requires a continued analysis, since the data from the life histories touched upon here reaches only the top of an iceberg.

\section{Discussion}

In this paper, the life courses of a small group of migrants and their spouses have been analyzed, as part of an ongoing study, which aims to explore and investigate under what health and life circumstances internal migrants lived, and how they coped with their everyday lives as new residents in a small pre-industrialized town. The first results concern a discerned "migrant profile" of men who faced problems in town. These problems were found to be at their heights when the men had a family to provide for but failed in doing so. Hence, it could be said to be a gender-related problem since it was expected that these men should support their family. Their failures could be due to different circumstances but their phase of life, is not an unimportant factor. Demographic findings from the industrialized 19th century Belgium suggest that family members of married migrant men have been found to suffer from an exposed socioeconomic situation and a high mortality. ${ }^{191}$ The conclusion from the Belgian study is that:

...the real challenge was not migrating to the boom towns at the heart of the industrial revolution, but raising a family in this new environment. Obviously, family history must become central to a new social history of the formation of the nineteenth-century working class. ${ }^{192}$

Although this paper deals with a different context and a different epoch with its particular small-town, pre-industrialized characteristics, there seem to be some common patterns here. One such pattern, besides the material conditions, which might have been even worse before industrialization brought about more job opportunities, could be the lack of social integration, which is related to social control and gender roles. Since the migrants in this study had spent a long period of time in town and were

190 Jan Sundin, "Livet i den förindustriella staden: Om det goda livets sociala villkor", in Det goda livet, ed. Per Månson (Daidalos, Göteborg, 2001), p. 98.

191 M. Oris and G. Alter (2001), p. 470, 480. Middle aged men has also been shown to have a high mortality in early nineteenth century Sweden. See J. Sundin and S. Willner (2003), p. 66.

192 M. Oris and G. Alter (2001), p. 487. 
married when their problems were intensified, this would imply that they were socially integrated but this cannot be taken for granted and must be further explored. ${ }^{193}$ Previous research on individual, but "typical", cases in pre-industrialized Linköping, suggests that the proletarians were exposed to "social stress", worsened by the lack of social connections, which seems to be common among those who had previously moved to town. ${ }^{194}$

One step towards an understanding of this multifaceted issue, is to study the group of individuals around the spouses, for example acting as godparents of the migrants' children. ${ }^{195}$ Already started studies have shown that neighbours or workmates can be recognized as well, implying what social resources were at hand. This could help to indicate whether the migrants had strong bonds to their old homes or had acquaintances in town and if this could be gender related. ${ }^{196}$ Research concerning the town of Sundsvall indicates that migrant women seemed to have closer contact with their previous homes than migrant men and therefore might have had an easier task adapting in town. ${ }^{197}$

Finally, this study shows only a fragment of the picture of the migrant men's destinies in a family context. A comparison must be made with the other individuals in the cohort who are not found to be 'migrant men in misery'. The results suggest that a focus in the continuing study can be put on the migrants' parenting phase of life in further thematic investigations, viewed from a gender perspective. The impact of time and setting, could be highlighted by a generational approach regarding these matters.

Victoria Nygren is $\mathrm{PhD}$-candidate at the Department of Health and Society, Linköping University, Linköping, Sweden. E-mail address: vicny@ihs.liu.se.

\section{Acknowledgement}

The ongoing study is a dissertation which is planned to be finished by the end of 2007/beginning of 2008. This paper is a revised version of a paper presented at the PhoenixTN Conference, "The Price of Life: Welfare Systems, Social Nets and Economic Growth”, Catania, Italy, June 17th-18th , 2005.

193 See for instance, Jan Lucassen and Leo Lucassen, "Migration, migration history, history: Old paradigms and new perspectives", in Migration, migration history, history: Old paradigms and new perspectives (Peter Lang, Berlin, 1999), p. 21ff. They view social integration, regarding immigration, as a prolonged process extended over generations.

194 J. Sundin and S. Willner (2003), p. 48.

195 Compare M. Oris (2000), p. 410. He suggests a similar study, looking for marriage witnesses.

196 These results will be reported in the ongoing study.

197 L. Vikström (Umeå, 2003), p. $150 f$. 


\section{Printed Sources}

Östgöta Correspondenten, 18390817.

\section{Unprinted sources}

Demographic Data base (DDB), Umeå University/Linköpings Historiska Databas (LHD), Linköping University

Computerized Church records, Linköpings Domkyrkoförsamling and the Linköping region.

\section{Demographic Data Base, Umeå University}

Tabellverket, digitalized by DDB, Umeå University [http://www.ddb.umu.se/ visualisering/Tabverk/FormF320].

Tabellverket, digitalized by DDB, Umeå University [http://www.ddb.umu.se/ visualisering/Tabverk/FormF520].

\section{Genline [http://www.genline.com/]}

Digitalized Church records.

Landsarkivet $i$ Vadstena [The Regional Archives in Vadstena]

Bouppteckning, 1852, vol. B 66.

$$
\begin{gathered}
\text { Landstingets arkiv } i \text { Östergötland } \\
\text { [Landstinget's Archive in the County of Östergötland] }
\end{gathered}
$$

Länslasarettet i Vadstena, Överläkarens arkiv, Journaler vid Wadstena Kurhus, 1844, 1846. 


\section{Medicinhistorisk databas [Medical History Database], Linköping University}

Medicinalstyrelsen, C. A. Rosborg, Årsberättelse från Provinsialläkare, 1860 i Trosa. RA/420177.03. Rapport 90/181, Diarienummer 1220/61, vol. SK:30, http://pub.ep.liu.se/medhist/dokument/provlak/1860/P8600488.htm, (2007-0709).

Medicinalstyrelsens föregångare/Sundhetskollegium, L. Lindegren, Årsberättelse från Provinsialläkare 1844 i Linköping. RA/420177.03, Rapport 22/90, Diarienummer $1453 / 1845$, vol. 14,

http://pub.ep.liu.se/medhist/dokument/provlak/1844/P8440580.htm, (2007-07-09).

\section{Riksarkivet, SVAR [Swedish Archive Information - a Department of the National Archives]}

Church records on Micro cards.

\section{References}

Artæus I., Kvinnorna som blev över: Ensamstående stadskvinnor under 1800-talets första hälft-fallet Västerås. Studia historica upsaliensia, 170 (Uppsala, 1992).

Beebink E., Poppel van F. and Liefbroer C. A., "Parental Death and Death of the Child; Common Causes or Direct Effects?", in When Dad Died: Individuals and Families Coping with Distress in Past Societies, eds., Derosas R. \& Oris M. (Peter Lang, Bern, 2002).

Bengtsson M., Det hotade barnet:Tre generationers spädbarns- och barnadödlighet $i$ 1800-talets Linköping. Linköping Studies in Arts and Science, 145 (Linköping, 1996).

Bengtsson M., "The Interpretation of Cause of Death Among Infants", Hygiea Internationalis, 3:3 (2002), 53-73. [http://www.ep.liu.se/ej/hygiea/].

Breschi M. and Menfredini M., "Parental Loss and Kin Networks: Demographic Repercussions in a Rural Italian Village", in Derozas R. \& Oris M. eds., (2002).

Brändström A., "De kärlekslösa mödrarna": Spädbarnsdödligheten i Sverige under 1800talet med särskild hänsyn till Nedertornea. Umeå Studies in the Humanities, 62 (Umeå, 1984).

Brändström A., Sundin J., Tedebrand L-G., "Marriage and Urban Adaption: Sundsvall and Linköping in XIXth Century Sweden", Annales de démographie historique, 2 (1999).

Brändström A., Sundin J., Tedebrand L-G., "Two Cities: Urban Migration and Settlement in Nineteenth-Century Sweden", The History of the Family, 5:4 (2000). 
Carlsson S., Yrken och sambällsgrupper: Den sociala omgrupperingen i Sverige efter 1866 (Almqvist \& Wiksell, Stockholm, 1968).

Dribe M., "Migration of rural families in 19th century southern Sweden. A longitudinal analysis of local migration patterns", The History of the Family, vol. 8, (2003), p. 247-265.

Durkheim E. (Le Suicide, orig. 1897), Självmordet (Argos Förlags AB, Uppsala, 1968).

Edvinsson S. and Nilsson H., "Swedish towns during industrialization", Annales de démographie Historique, vol. 2 (1999).

Gabaccia D., "The Transplanted: Women and Family in Immigrant America", Social Science History, vol. 12 (1988), 243-253.

Gaunt D., Familjeliv i Norden (Gidlunds, Stockholm, 1983).

Green N., "The comparative method and poststructural structuralism: new perspectives for migration studies”, in Lucassen J. \& Lucassen, L., eds., Migration, Migration History, History: Old Paradigms and New Perspectives (Wien, 1999).

Gustafsson R. A.., Traditionernas ok: Den svenska hälso- och sjukvårdens organisering $i$ historie-sociologiskt perspektiv (Esselte studium, Solna, 1987).

Hedenborg S., "To breastfeed another womans's child: wet-nursing in Stockholm, 1777-1937", Continuity and Change, 16:3 (2001).

Hareven T. K., "Introduction: The Historical study of the Life Course", in Transitions: The Family and the Life Course in Historical Perspective, ed., Hareven T. K. (Academic Press, New York, 1978).

Hareven T. K., "The History of the Family and the Complexity of Social Change", American Historical Review, 96:1 (1991).

Hareven T. K., "Aging and Generational Relations: A Historical and Life Course Perspective", Annual Review of Sociology, vol. 20 (1994).

Hareven T. K., "What Difference does it make?", Social Science History, 20:3 (1996a)

Hareven T. K., "The generation in the middle: Cohort comparisons in assistance to aging parents in an American community", in Aging and generational relations over the life course: A historical and cross-cultural perspective, ed. Hareven T. K. (Aldine de Gruyter, New York, 1996b).

Hoerder D., Cultures in Contact: World Migrations in the Second Millennium (Duke University Press, Durham \& London, 2002).

Harnesk B., "Patriarkalism och lönearbete", Historisk tidskrift, vol. 3, (1986).

Harnesk B., Legofolk: Drängar, pigor och bönder i 1700- och 1800-talens Sverige. Umeå Studies in the humanities, 96 (Umeå, 1990).

Hellspong M., "Städer", in Land och stad: Svenska sambällen och livsformer frän medeltid till nutid, Hellspong M. \& Löfgren O. eds., (Gleerups, Malmö, 2001).

Högman A-K., "Elderly migrants in a northern Swedish town in the nineteenth century", Continuity and Change, vol. 16 (2001), 423-442.

Jackson J. Jr. and Moch L. P., "Migration and the Social History of Modern Europe", in European Migrants: Global and Local Perspectives, eds., Hoerder D. \& Moch L. P. (Northeastern University Press, Boston, 1996). 
Kertzer D. I., "Household, History and Sociological Theory", Annual Review of Sociology, vol. 17 (1991).

Laslett P., "Family, kinship and collectivity as systems of support in pre-industrial Europe: a consideration of the 'nuclear-hardskip' hypothesis", Continuity and Change, 3:2 (1988).

Lindberg F., Linköpings Historia 3. 1576-1862 Sambälls- och kulturliv (Linköping, 1976).

Lucassen J. and Lucassen L., "Migration, Migration History, History: Old Paradigms and New Perspectives", in Migration, Migration History, History: Old Paradigms and New Perspectives, eds., Lucassen J. \& Lucassen L. (Peter Lang, Bern, 1999).

Lunander E., "Bland handlare och hantverkare i en svensk landsortsstad under 1800talet: Om hushåll och familjestruktur i Örebro", in Den utsatta familjen: Liv, arbete och samlevnad $i$ olika nordiska miljöer under de senaste två hundra åren, ed., Norman H. (LTs förlag, Stockholm, 1983).

Lundberg A., Care and Coercion: Medical Knowledge, Social Policy and Patients with Veneral Disease in Sweden 1785-1903. Report no. 14 from the Demographic Database (Umeå, 1999).

Manfredini M., "Families in motion: The role and characteristics of household migration in a 19th century rural Italian parish", History of the Family, vol. 8 (2003), 317-343.

Martinius S., Jordbrukets omvandling på 1700- och 1800-talen (Liber förlag, Lund, 1982).

Matovic M., "Migration, Family Formation, and Choice of Marriage Partners in Stockholm, 1860-1890", in Urbanization in History: A Process of Dynamic Interactions, eds., Woude van der AD, Hayami A. \& Vries de J. (Clarendon Press, Oxford, 1990).

Moch L. P., Moving Europeans: Migration in Western Europe since 1650 (Bloomington \& Indianapolis, 1992).

Moch L. P., Paths to the City: Regional Migration in Nineteenth-Century France (Sage Publications, Beverly Hills, 1983).

Montgomery A., Svensk socialpolitik under 1800-talet (Kooperativa förbundets bokförlag, Stockholm, 1951).

Neven M., "The influence of the wider kin group on individual life-course transitions: results form the Pays de Herve (Belgium), 1846-1900", Continuity and Change, 17:3 (2002).

Neven M., "Terra Incognita: Migration of the Elderly and the nuclear hardship hypothesis", The History of the Family, vol. 8 (2003).

Nilsson H., Mot bättre hälsa: Dödlighet och hälsoarbete i Linköping 1860-1894. Linköping Studies in Arts and Science, 105 (Linköping, 1994).

Nilsson H. and Tedebrand L-G, Familjer i växande städer: strukturer och strategier vid familjebildning i Sverige 1840-1940. Report no. 27 from the Demographic Database, Umeå University (Umeå, 2005). 
Nilsson H. and Willner S., Inflyttare till Linköping under 1800-talet. Rapport no. 6, Centrum för lokalhistoria i Linköping (Linköpings universitet, 1994).

Ohlander A-S., "Att vänta barn på bröllopsdagen: Föräktenskapliga förbindelser och giftermålsmönster i 1800-talets Sverige", in Kärlek, död och frihet: Historiska uppsatser om människovärde och livsvillkor i Sverige (Norstedts, Stockholm, 1986).

Oris M., "The age at marriage of migrants during the industrial revolution in the region of Liège", The History of the Family, vol. 5, No. 4 (2000).

Oris M. and Alter G., "Paths to the city and roads to death: Mortality and migration in east Belgium during the industrial revolution", in Revue belge d'Histoire contemporaine. Recent work in Belgian Historical Demography 19th and early 20th centuries, eds., Devos I. \& Neven M. (2001).

Oris M. and Ochiai E., "Family Crisis in the Context of Different Family System: Frameworks and Evidence on 'When Dad Died", in When Dad Died: Individuals and Families Coping with Distress in Past Societies, eds., Derosas R. \& Oris M. (Peter Lang, Bern, 2002).

Petersson B., "Debatten om 'Den sociala frågan'”, in Kontroll och kontrollerade: Formell och informell kontroll $i$ ett historiskt perspektiv, ed. Sundin J., Forskningsrapporter från Historiska institutionen vid Umeå universitet, no. 1 (Historiska institutionen vid Umeå universitet, Umeå, 1982).

Pleijel H., Hustavlans värld: Kyrkligt folkliv i äldre tiders Sverige (Verbum, Stockholm, 1970.

Plymoth B., Fostrande försörjning: Fattigvård, filantropi och genus i fabriksstaden Norrköping 1872-1914 (Almqvist \& Wiksell International, Stockholm, 2002).

Pooley C. G. and Doherty J. C., "The Longitudinal study of migration: Welsh migration to English towns in the nineteen century", in eds., Pooley C. G. \& Whyte I. D. (1991).

Pooley C. G. and Whyte I. D., "Introduction: approaches to the study of migration and social change", in Migrants, Emigrants and Immigrants: A Social History of Migration, eds., Pooley C. G. \& Whyte I. D: (Routledge, London \& New York, 1991).

Puranen B-I., Tuberkulos: En sjukdoms förekomst och dess orsaker. Sverige 1750-1980. Umeå Studies in Economic History, 7 (Umeå, 1984).

Reay B., "Kinship and the neighbourhood in nineteenth-century rural England: The myth of the autonomous nuclear family", Journal of Family History, 21:1 (1996).

Ryan Johansson S., "Welfare, Mortality, and Gender. Continuity and Change in Explanations for Male/Female Mortality over three Centuries", Continuity and Change, 6:2 (1991).

Sewell Jr W. H., Structure and Mobility: The Men and Women of Marseilles, 1820-1870 (Cambridge University Press, Cambridge, 1985).

Siegrist J., "Place, social exchange and health: proposed sociological framework", Social Science and Medicine, vol. 51 (2000).

Sollinger G., Sjuk- och begravningskassorna och andra understödskassor i Kungl. bibliote- 
kets samlingar (Kungliga biblioteket, Stockholm, 1985).

Sundin J., "Äktenskap, ensamskap och hälsa förr och nu: Tankar kring ett forskningsfält", in Individ och struktur i historisk belysning. Festskrift till Sune Akerman, eds., Ericsson T. \& Guillemot A. Forskningsrapport no. 10. Historiska institutionen, Umeå universitet (Umeå, 1997).

Sundin J., "Worlds we have lost and worlds we may regain: Two centuries of changes in the life course in Sweden", The History of the Family, vol. 4, no. 1 (1999).

Sundin J., "Livet i den förindustriella staden: Om det goda livets sociala villkor", in Det goda livet, ed., Månson P. (Daidalos, Göteborg, 2001).

Sundin J.and Willner S., "Social stress, socialt kapital och hälsa: Välfärd och samhällsförändring i historia och nutid", in Sambällsförändring och hälsa: Olika forskarperspektiv, eds., Sundin J. \& Willner S. (Institutet för framtidsstudier, Stockholm, 2003).

Sundin J. and Willner S., "Health and Vulnerable Men. Sweden: From Traditional Farming to Industrialisation", Hygiea Internationalis, vol. 4, No. 1 (2004) [http://www.ep.liu.se/ej/hygiea/].

Taussi Sjöberg M., Dufvans fångar: Brottet, straffet och människan i 1800-talets Sverige (Författarförlaget, Stockholm, 1986).

Taussi Sjöberg M., Skiljas: Trolovning, äktenskap och skilsmässa i Norrland på 1800talet (Författarförlaget, Stockholm, 1988).

Thomson D., "The welfare of the elderly in the past: A family or community responsibility?", in Life, Death, and the Elderly: Historical Perspectives, eds., Pelling M. \& Smith R. M. (Routledge, London \& New York, 1991).

Thyresson N., Från franzoser till Aids: Kapitel ur de veneriska sjukdomarnas historia $i$ Sverige (Carlssons, Stockholm, 1991).

Tilly C., Big Structures, Large Processes, Huge Comparisons (Russell Sage Foundation, New York, 1984).

Tollstorp J. P., Beskrifning öfver Linköping (Föreningen gamla Linköping, Linköping, 1957, orig. 1834).

Umberson D., "Family Status and Health Behaviours: Social Control as a Dimension of Social Integration", Journal of Health and Social Behavior, 28:3 (1987).

Vikström L., Gendered Routes and Courses: The Socio-Spatial Mobility of Migrants in Nineteenth-Century Sundsvall, Sweden. Report no. 21 from the Demographic Data Base, Umeå University, 2003 (Umeå, 2003).

Willner S., Det svaga könet? Kön och vuxendödlighet i 1800-talets Sverige. Linköping Studies in Arts and Science, 203 (Linköping, 1999).

Winberg C., Folkökning och proletarisering: Kring den sociala strukturomvandlingen på Sveriges landsbygd under den agrara revolutionen. Meddelanden från Historiska institutionen i Göteborg (Göteborg, 1975).

Yans-McLaughlin V., "Metaphores of Self in History: Subjectivity, Oral Narrative, and Immigration Studies" in Immigration Reconsidered: History, Sociology, and 
Politics, ed., Yans McLaughlin V. (New York \& Oxford, Oxford University Press, 1990).

Åkerman S., Högberg U. and Andersson T., "Survival of Orphans in NineteenthCentury Sweden", in Orphans and Fosterchildren: A Historical and Cross-Cultural Perspective, ed., Tedebrand L-G., Report No. 11 from the Demographic database (Umeå, 1996).

Öhngren B., "Urbaniseringen i Sverige 1840-1920", in Urbaniseringsprosessen i Norden, del 3. Industrialiseringens forste fase, ed., Authén Blom G. (Universitetsforlaget, Oslo, 1977). 